\title{
مستوى الضغوط النفسية الناتجة عن انتشار فيروس كورونا المستجد (COVID-19) لاى عينة من أفر اد الجالية الأردنية في حائل فئل
}

\author{
د. سمر صيتان الصمادي \\ أستاذ مساعد، قسم علم النفس، كلبية التربية الهبية \\ جامعة حائل المدلكة العربة العربية السعودية.
}

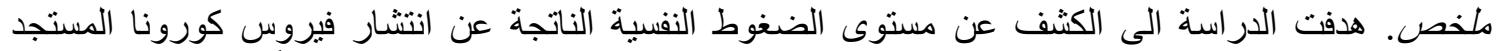

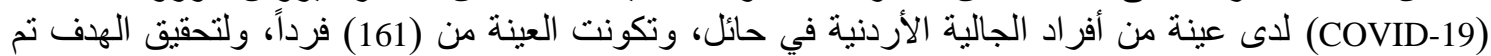

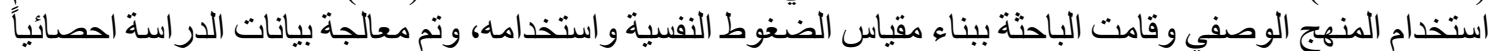

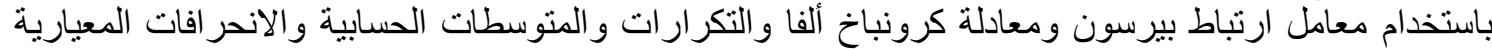

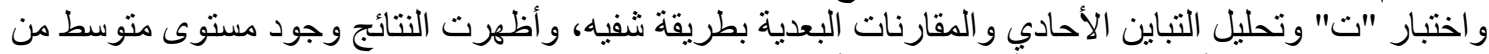

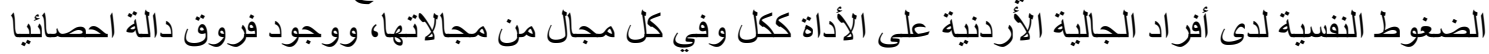

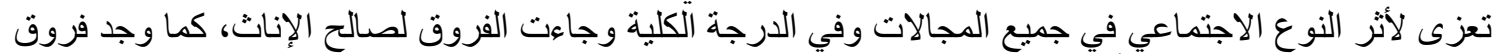

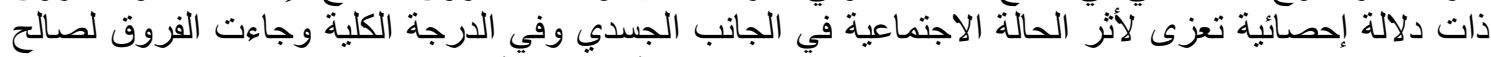

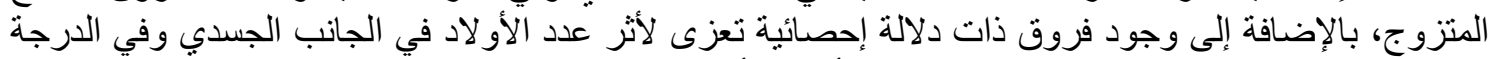

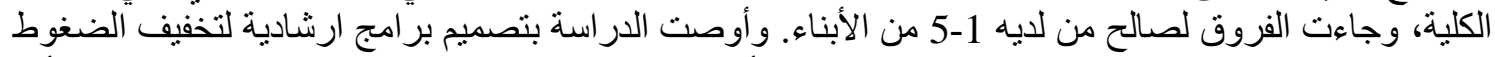

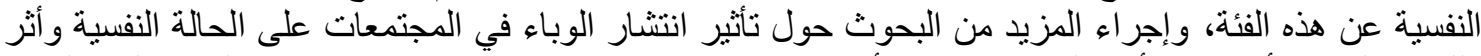

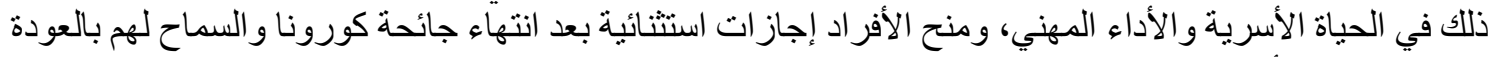

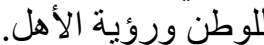
الكلمات المفتاحية: الحجر الصحي المنزلي، الإجراءات الاحترازية، التباعد الاجتماعي، حظر التجول، الضغط

فالضغوط النفسية لها الكثير من التداعيات السلبية

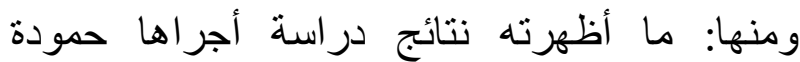

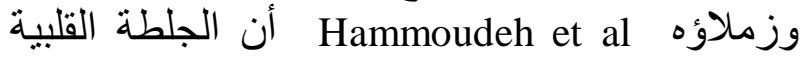

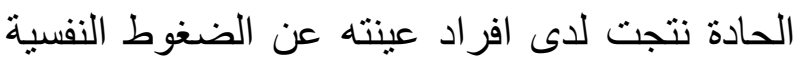
الناتجة عن انتشار فيروس كورونا المستجد

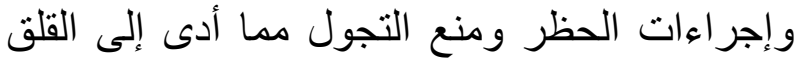

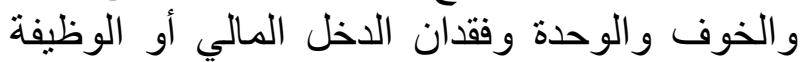

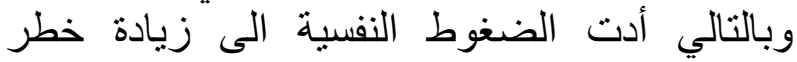

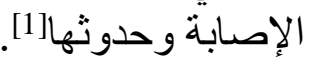
وقد بدأ انتشار فيروس كورونا المستجد في الصين ثم الثم

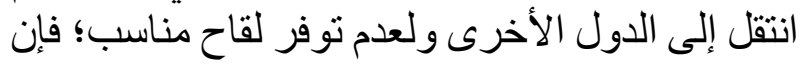
الطريقة الوحيدة للوقاية منه هي باتباع الارشئ لإدادات

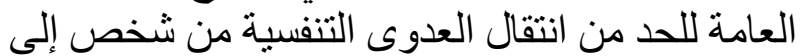
آخر [2]. وقد انتشر المرض على التفل نطاق واسع وسريع في الصين و العديد من البلدان الأخرى، مما تسبب في في

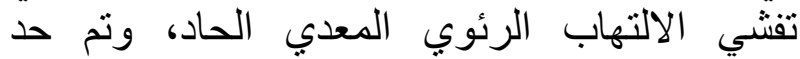
العلاقات العامة من خلاب الحجر الصحي الصدي المنزلي

\section{المقدمة}

تسعى الحكومات جاهدة للحد من انتشار فيروس المدة

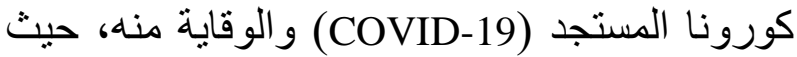

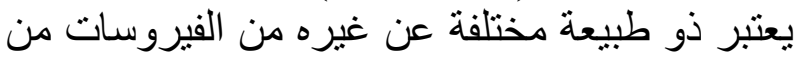

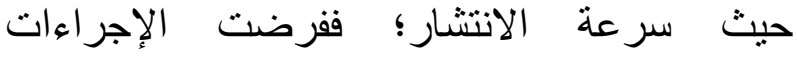

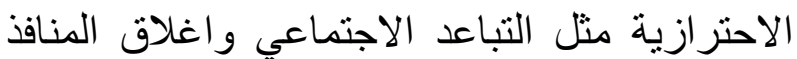

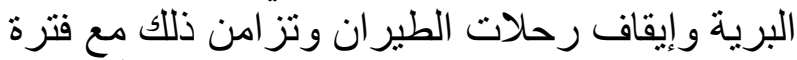

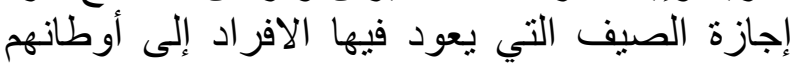

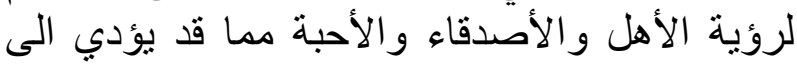
شعور هم بالتوثر والضيق النفسي وترقب فتح الآح الحدود

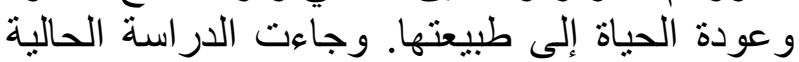

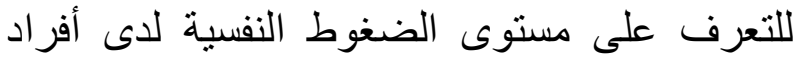
الجالية الأردنية؛ ولتكون مدخلا لتقليل التداعيات

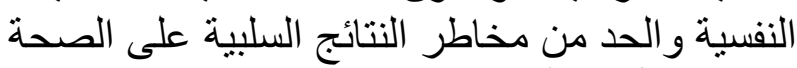

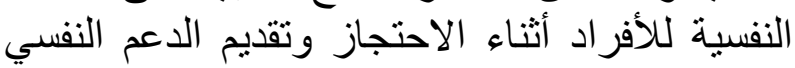
للهم في مثل هذه الظروف. لافر الناع. 
الرذاذ التنفسي الصادر عنه أثناء السعال أو العطس، أو ملامسة الأسطح الملوثة بالفيروس. ويستطيع هذا لألئ

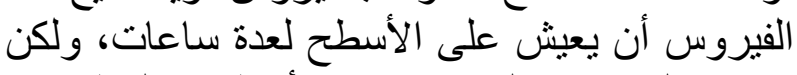

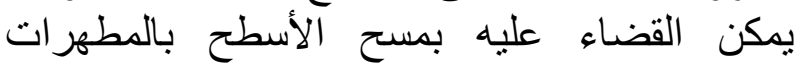

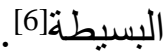

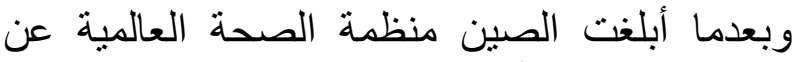

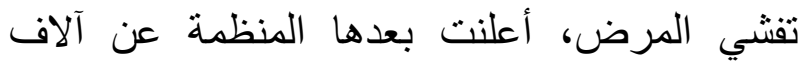
الحالات المؤكدة أصابتها بالفيروس خارجة الصدهات الصين، لذلك خلصت منظمة الصحة العالمية إلى تقييم مؤداه: أن فيروس كورونا المستجد (COVID-19) ينطبق هونة عليه وصف جائحة، وروناعتبرته حالة طوارئ صحية

عالمية [7]. وقد أثز ظهور الفيروس في مدينة ووهان الصينية

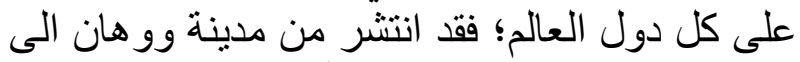

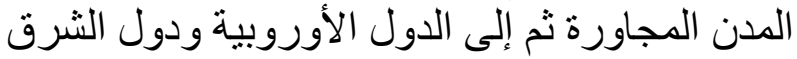

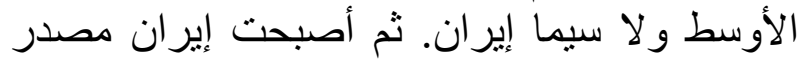
رئيسي له في الثرق الأوسط، و هذا دفع دول المنطقة النية

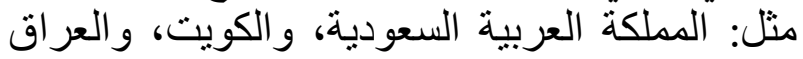

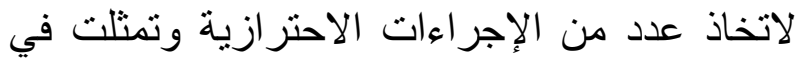

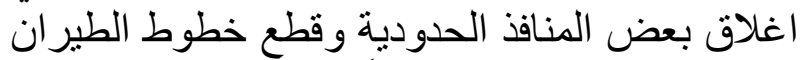

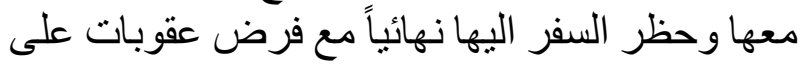
من يخالف هذه القو اعد [8] الحجر الصحي والتباعد الاجتماعي: يعد الحجر الصدي من أقدم الطرق والكي أكثر ها فعالية في

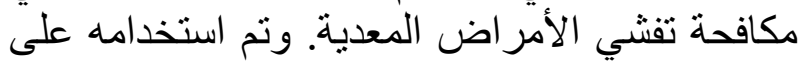

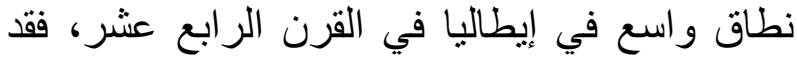

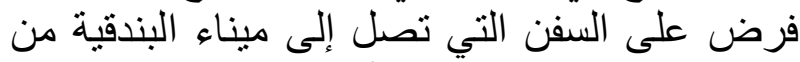

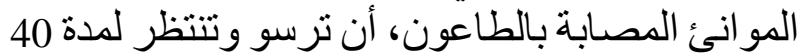

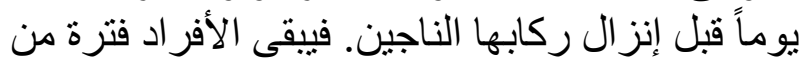
الوقت حتى يكتمل وقت الحضانة للمرض لكي لتئ تمييز الحالات المريضة. كما تم تنفيذه بنجاح كإجر اء فئه فعال خلال فترة انتشار وباء (SARS) في عام 2003.

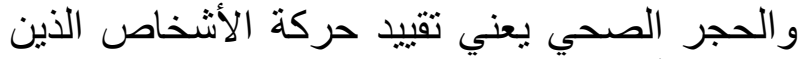
يفترض أنهم تعرضوا لمرض لهن معدي ولكنهم ليسوا

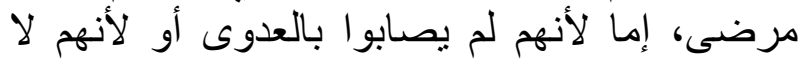
يز الون في فترة الحضانة. ويمكن تطبيقه على الفرد أو المجموعة ضمن فيتوة فيات، يتم فيه إلز ام الأفراد بالبقاء في المنزل وقد يكون طو عياً أو الز امياً. وأثناء الزئ

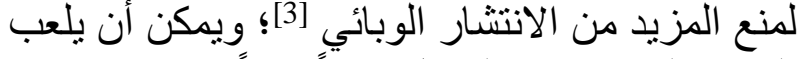

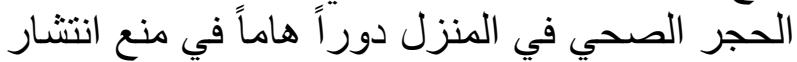

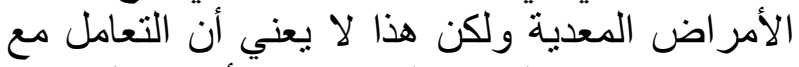

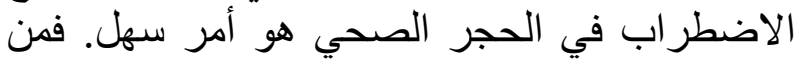

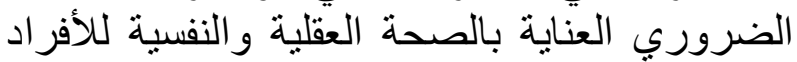

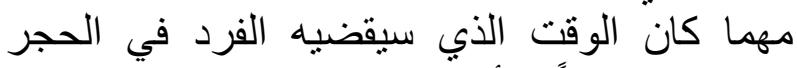
الصحي قصيراً. و أدى تفثي الفيروس الصي إلى التباعد

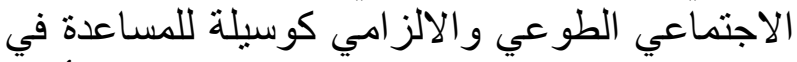

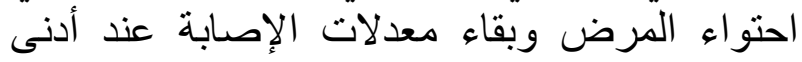

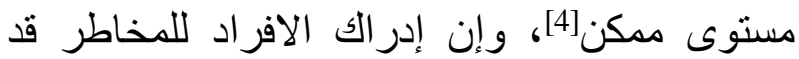

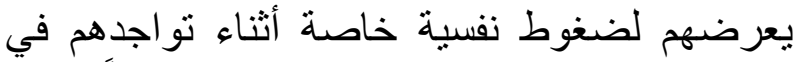
الحجر الصحي المنزلي المفروض عليهم منعاً لزيادة

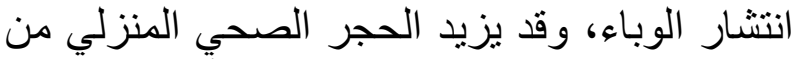

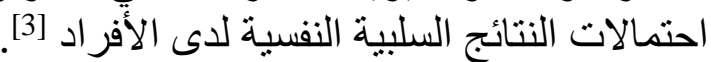
التعريف بفيروس كورونا المستجد (COVID-19):

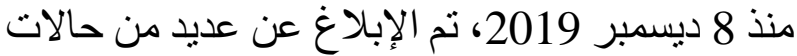
الالتهاب الرئوي لمسببات مرضية غير غير معروفة في

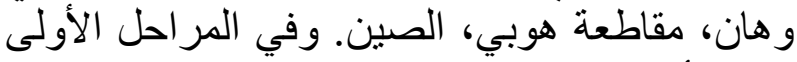

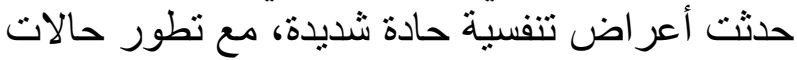

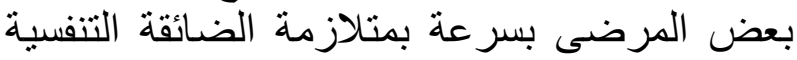

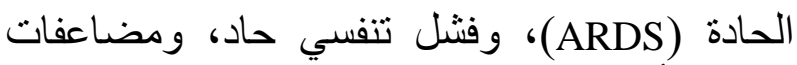

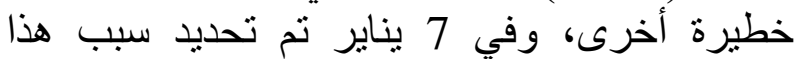
الالتهاب من خلال عينة مسحة الحلق للمريض وفير وظهر أنه فيروس تاجي جديد وتم تسميته لاحقاً

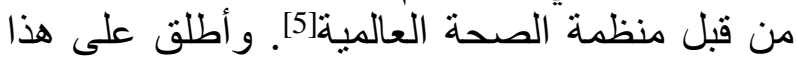
المرض الناتج عن الفيروس التاجي الجديد اسم مرض الفي الفي

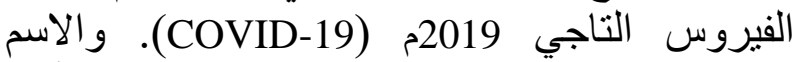
الإنجليزي للمرض مشتق كالآتي: CO هما أول

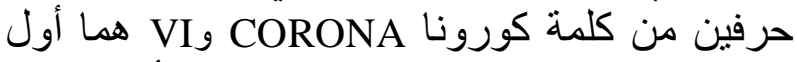

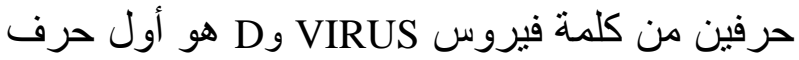
من كلمة مرض بالإنجليزية Disease. و أطلق على هنى هذا

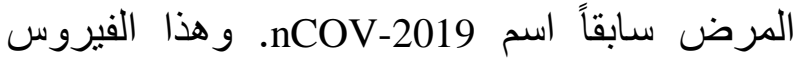
يرتبط بعائلة فيروسات كورونا التي ينتمي اليها الفيروس الذي يتسبب بمرض فير المتلازمة التنفسية

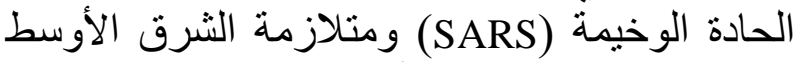

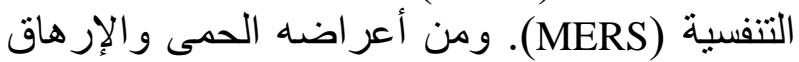

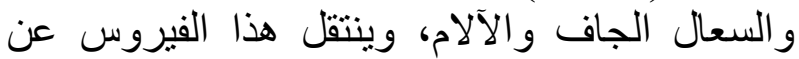
طريق الاتصال المباشر مع شخص مصاب من خلابل 
متعددة منها: الاعر اض الجسدية مثل: (الصداع، شند

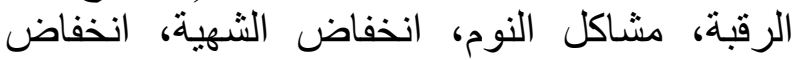
الطاقة و التعب). و الاعر اض النفية النفية و العاطفية مثل:

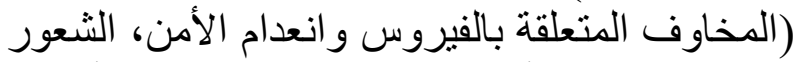

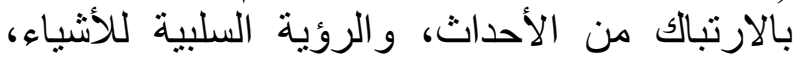

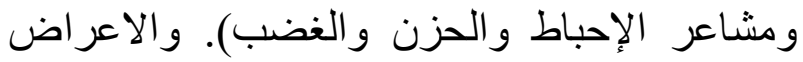
السلوكية مثل: (صعوبة في الإهية التركيز، و والتهيج

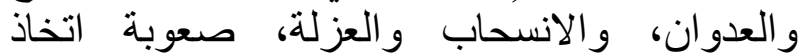

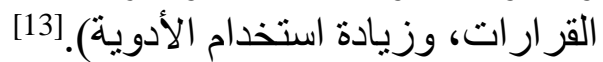
الإجراءات الاحترازية في المملكة العربية السية السعودية العادية

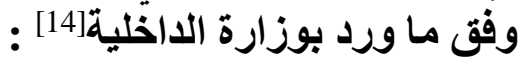

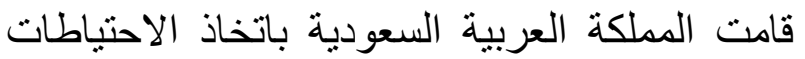
والإجر اءات الاحتر ازية اللازمة لمحاولة منع النتشار

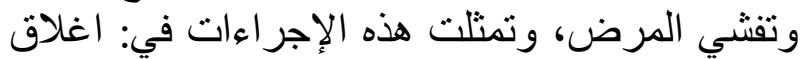

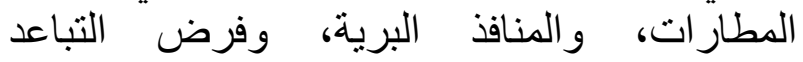
الاجتماعي، وحظر التجول في جميع مناطق المملكة،

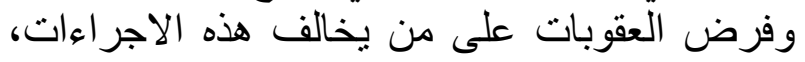

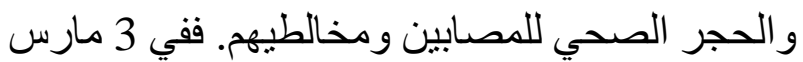

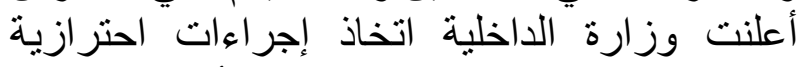

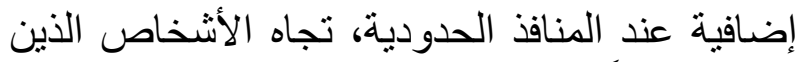
زاروا دولاً موبوءة بفيروس كورونا المستجد

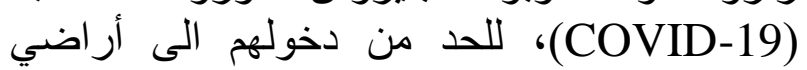
المملكة اثتاء فترة حضانة الفيروس.

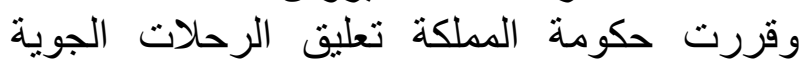

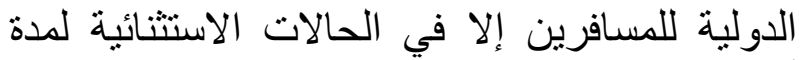

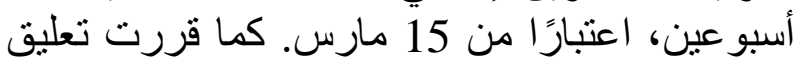

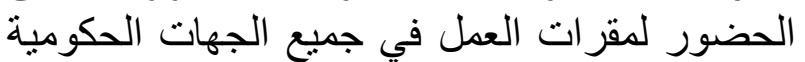

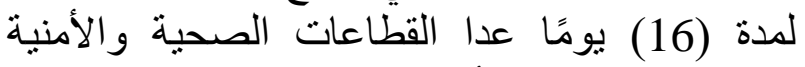
و العسكرية ومركز الأمن الإلكتروني. وتمات تعليق جميع

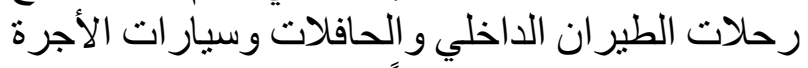

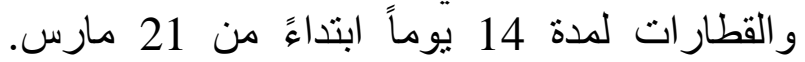
و أصدر خادم الحرمين الثريفين أمره بمنع التجول

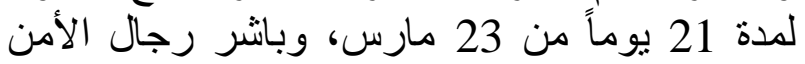
تطبيق منع التجول في جميع أنحاء المملكة. ومعاقبة

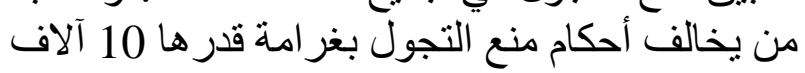

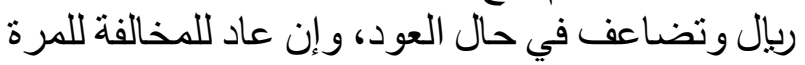

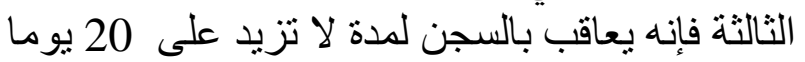

الحجر الصحي يجب مراقبة جميع الأفراد تجنباً

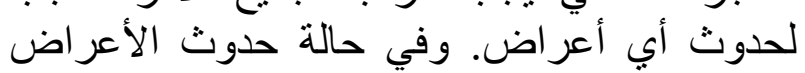

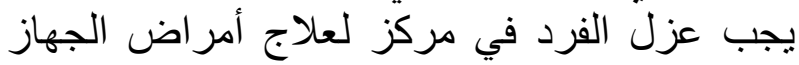
التنفسي. ويعتبر الحجر الصحي والتباعد الاجتماعي التاعي مثل: (اغلاق المدارس و إلغاء التجمعات في التهات الأماكن

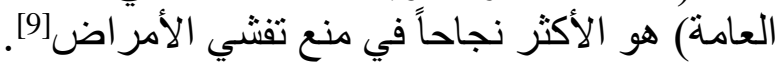

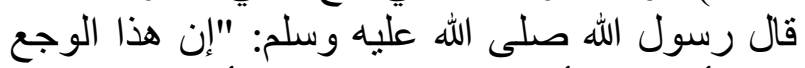

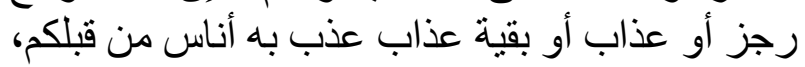

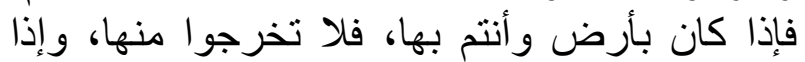

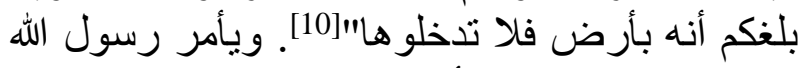

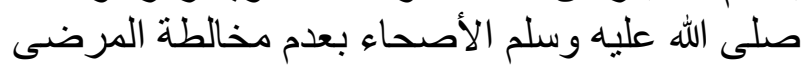
بمرض معدي، فعندما جاء و فد ثقيف كان من ضدمنهم الاهم رجلّ مجذوم، فأرسل إليه رسول الله صلى صلى الله عليه

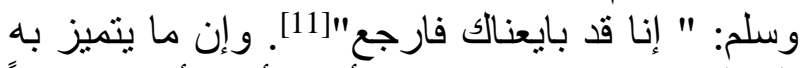
المسلم عن غيره في هذا الأمر، أنه مأمور شرعاً

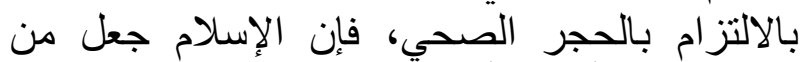

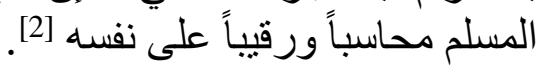

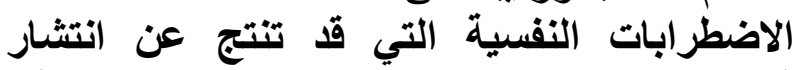
فيروس كورونا المستجد (COVID-19) والبقاء في في الإني الحجر الصحي المنزلي : تسبب انتنار فِيروس كورونا المستجد المبن (COVID-19)

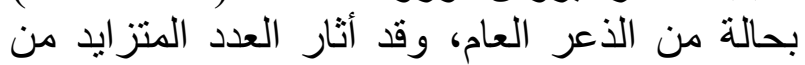

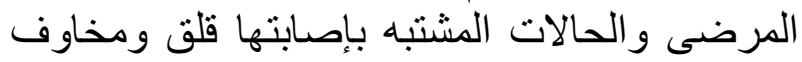

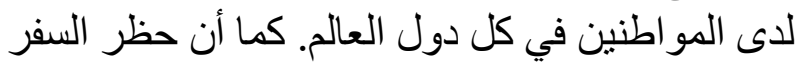
و التنقل بين البلدان والاو امر التنفيذية لحجر المبن المسافرين

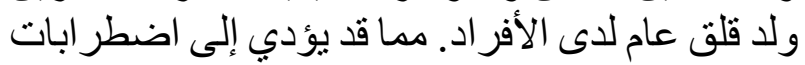

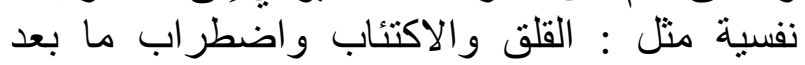

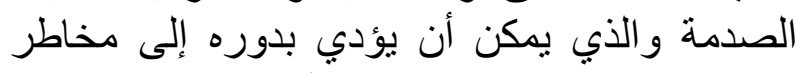

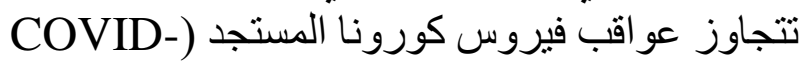
19) نفسهان وورد في Québec أن جائحة الفيروس التاجي الحالي

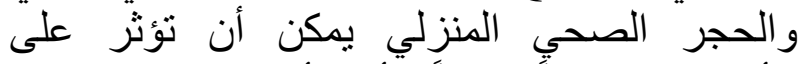
الأشخاص جسدياً ونفسياً. وأن الأفر اد المحتجزين فئ فئ

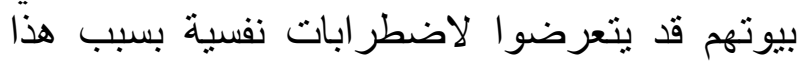

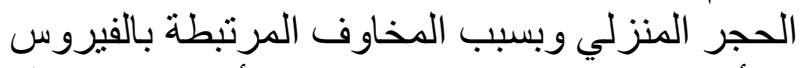
و الأخبار عنه وتفشيه، مما قد يؤدي لأعر اض اض محتملة

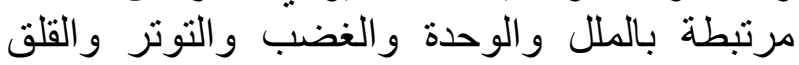
و الاكتئاب، ويمكن أن تظهر هذه الاعر اض بصور 


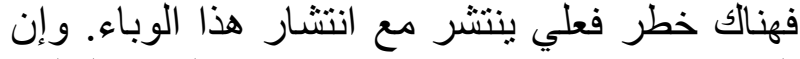
التباعد الاجتماعي قد فيزيد من احتمالات النتائج السلبية النفسية[3] ويتعرض الأفراد في مراحل حياتهم إلى الكثير من

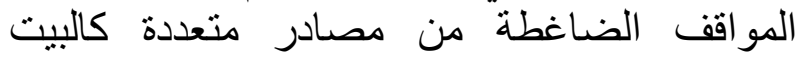

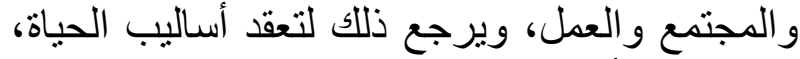

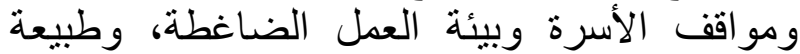

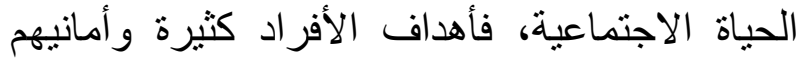

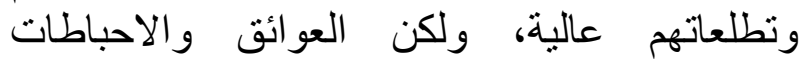

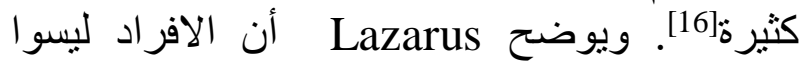
ضحايا للتوتر و المواقف الضاغطة ولكن كيفية

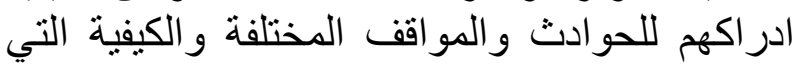

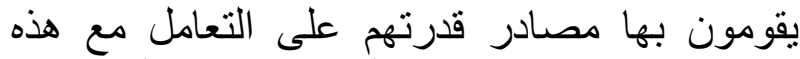
المواقف، هما اللتان تقرر ان أن هذا الموقف أو أو الحدث

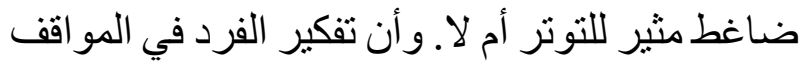

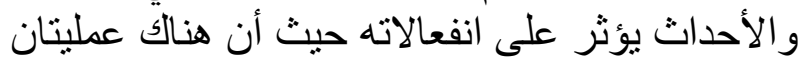

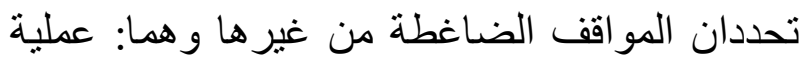

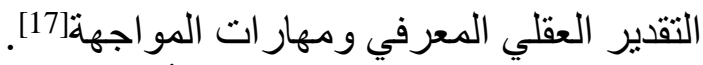

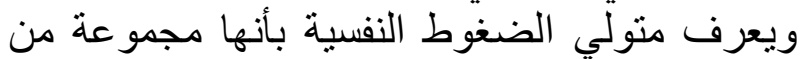
الأحداث الضأغطة و التي تشكل تهديداً للفرد، لأنها

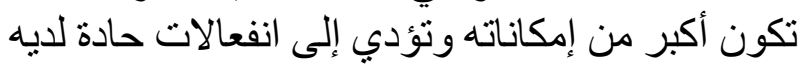
ومستمرة ويصاحبها مظاهر سلبية تنعكس على البى أداء

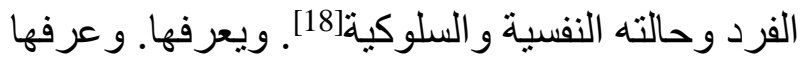

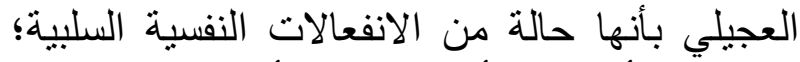

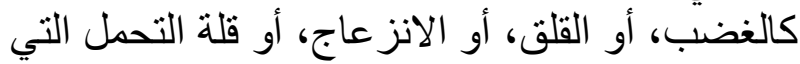

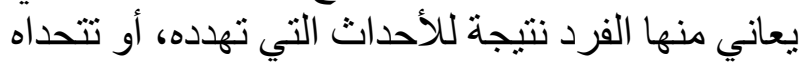
بجميع فعاليات الحياة[19].

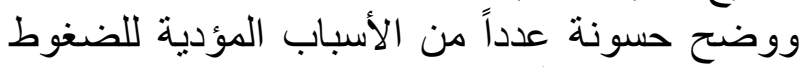

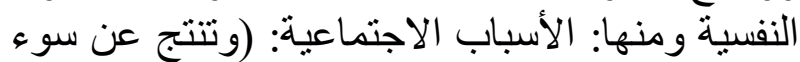

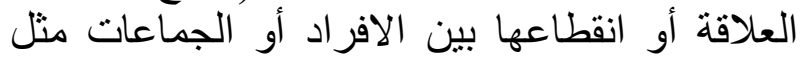

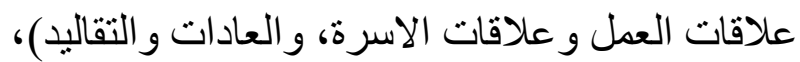

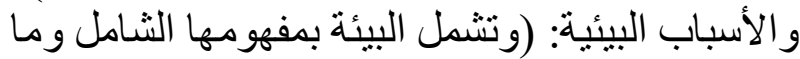

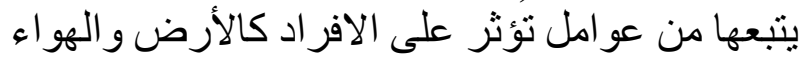

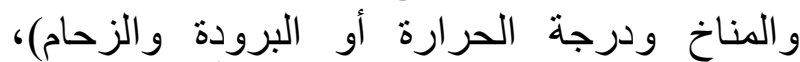
والأسباب النفسية: (وهي الأكثر تأثيراً على الأفراد التهاد

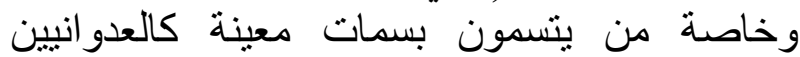

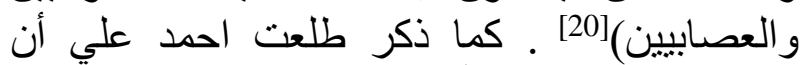
للضغوط النفسية أنو اعاً يمكن أن تصنف بحسب آثنار ها
و لا يسري ذللك على حالات الضرورة القصوى وفقاً لما تحدده الجهة المختصة فئ. فئ هالت وفي 29 مارس تم تمديد العمل بتعليق الحضور الحفية لمقرات العمل وتعليق الرحلات الجوية الدولية

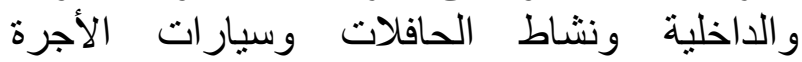
و القطار ات. وفي 12 ابريل صدر أمر خادم الحرمين الثريفين بالمو افقة على تمديد العمل بمنع التجول.

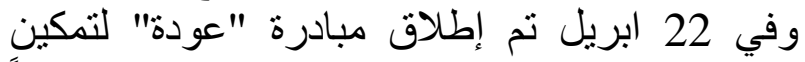

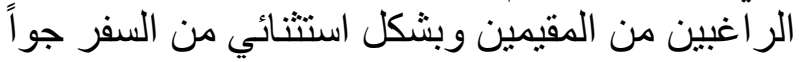

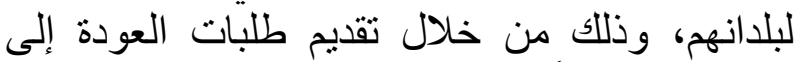

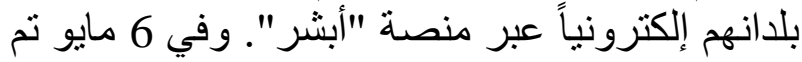
إتاحة التسجيل وبشكل استثنائي لجميع الجنسيات في في التي

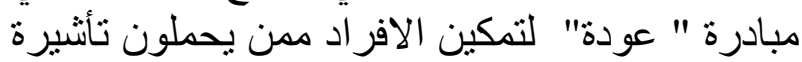

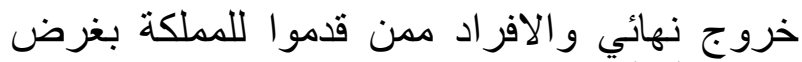
الزيارة أو أداء العمرة من العودة إلى إلى بلادهم.

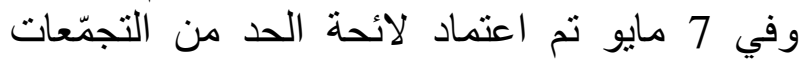

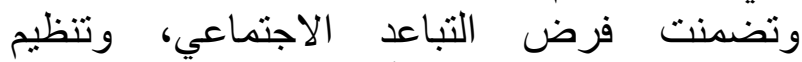

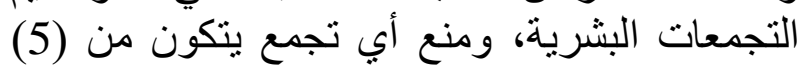

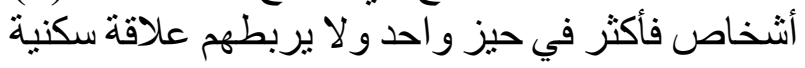

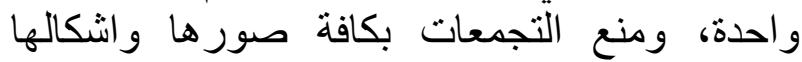

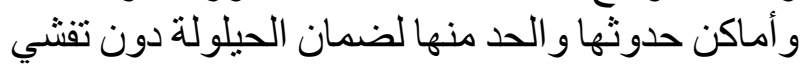
الفيروس. وصدرت الموافقة الكريمة على رفي رفع منع

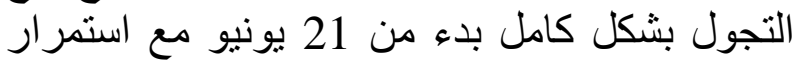
تعليق العمرة والزيارة وتعليق الرحلات الدولية.

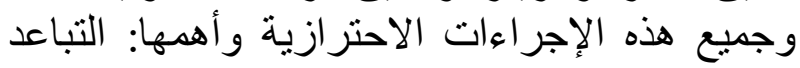

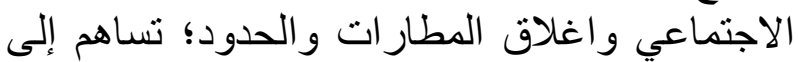

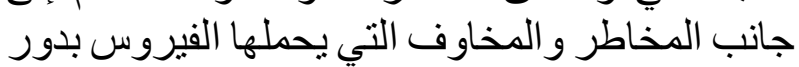
كبير في رفع مستوى الضغوط النفية النفية لدى أفراد

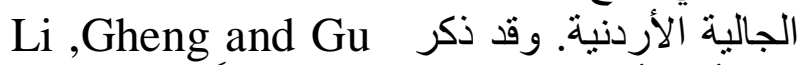
[15]بأن الأشخاص الذاصنة ولأنين يعيشون بعيداً عن عائلاتهم

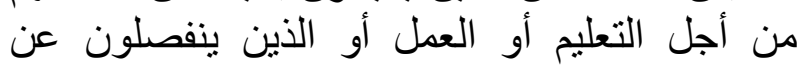
أحبائهم بطريقة أخرى يكونون أكثر عرضة التهن للإصنابة بمشاكل الصحة العقلية مثل الإكتئاب و القلق.

الضغوط التفسية:

إن إدر الك الافر اد للمخاطر قد يعرضهه لضغوط الضغ نفسية

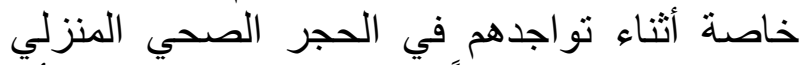

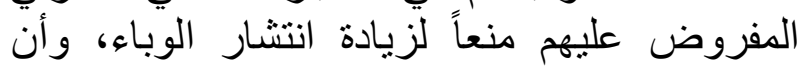

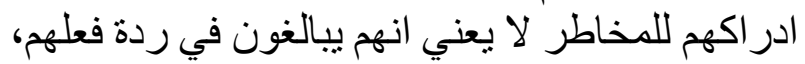


الجامعة، كما يعانون بدرجة منوسطة من المشكلات

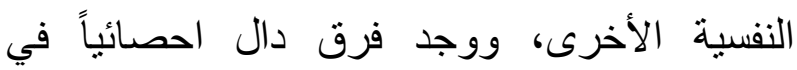

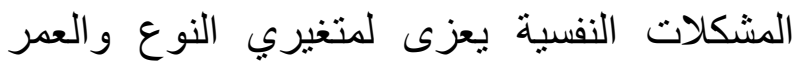

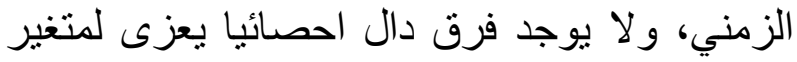
البيئة. و وانتهت الدر اسة ببعض الترفي التوصيات.

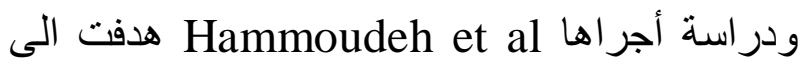
الكثف عن الأحداث و الضغوط الها التي أدت إلى حدوث الجلطات القلبية لدى أفراد العينة حيث تكونت العينة من (55) من المرضى غير المصابين بفيروس

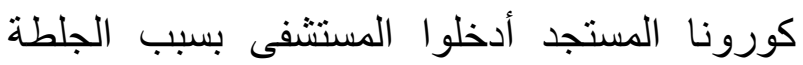
القلبية الحادة، وكان أفراد العينة ممن لايهم عوامل لكل خطر الإصابة بتصلب الثر ايين كالتدخين والسكري

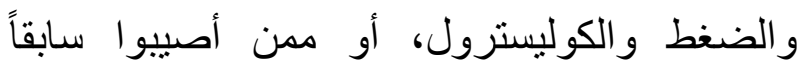

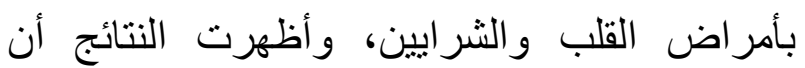
الجلطة القلبية الحادة نتجت عن الضغوط النفسية الناتجة عن انتشار فيروس كورونا المستجد

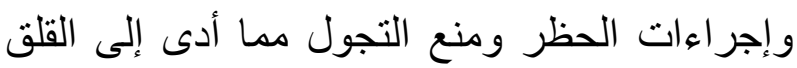
والخوف والوحدة وفقدان الدخل المالي أو الوظيفة

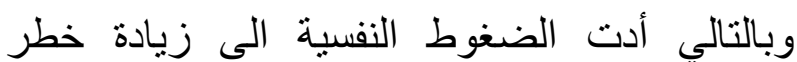
الإصابة وحدوثها]1]. وفي دراسة Mustafa و التي هدفت إلى التحقق من الإن التهان وجود الضغوط النفسية و العو امل المصاحبة لها خلال المرحلة المبكرة من تفشي فيروس كورونا المستجد (COVID-19) و الاستعداد للطو ارئ الصحية العامة، وتكونت العينة من (1130) فرداً من (28) مدينة في تركيا، أظهرت

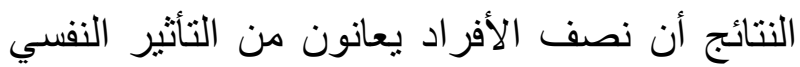

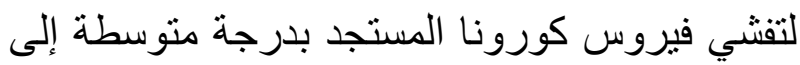

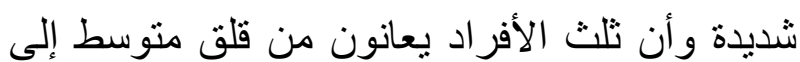

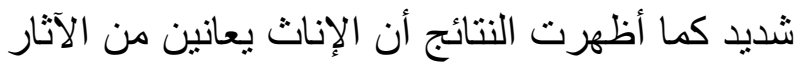

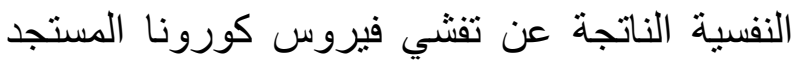

إلى: (الضغوط الإيجابية و الضغوط السلبية)، وبحسب

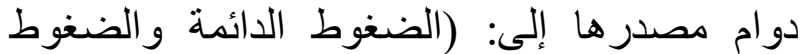
المؤقتة) [21].

وذكرت الغامدي أن للضغوط النفسية بجميع أنو اعها

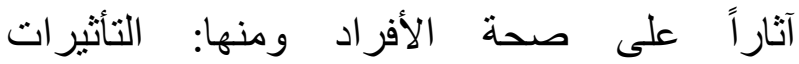
الفسيولوجية: فردود فعل الجسم لمتطلبات الضغط تهيئ الجسم ليكون على استعداد للاستجابة للتحديات و الضغوط، و التأثير ات النفسية: فالعو امل النفسية تؤثر على الأفر اد بشكل إيجابي وبشكل سلبي، فعندما تكون هذه العو امل في مستوى طبيعي فأنها تثير الدافعية لدى الدى الفرد، ولكنها إذا زادت عن قدرته على التكيف معها فإنها تصبح سلبية وتستنزف طاقته النفسية وقد يحدث النيا لديه الاضطر اب النفسي، والتأثنيرات الانفعالية: مثل ضعف القدرة على الاسترخاء ويختفي الإحساس بالصحة و السعادة، والتأثير ات المعرفية: مثل النسيان وصعوبة في التركيز و اتخاذ القرارات، و التأثيرات السلوكية: مثل نقص الميول ونقص الحماس وعدم الرغبة بممارسة الهوايات، و التأثثير ات الاجتماعية: فتؤثر على العلاقات في المنزل و العمل و المجتمع [22]. وقد أجرى بعض الباحثين دراسات تتعلق بالضغوط فئرل و المشكلات النفسية الناتجة عن انتشار فيروس كورونا المستجد (COVID-19) في المجتمعات ومن ضمن

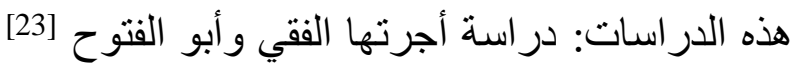
وكان هدفها التعرف على طبيعة بعض المشكلات

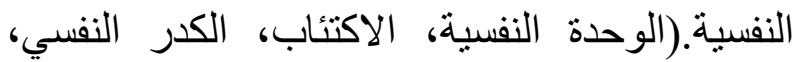

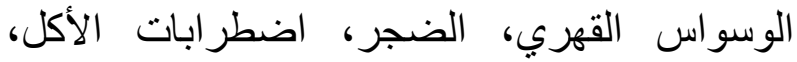

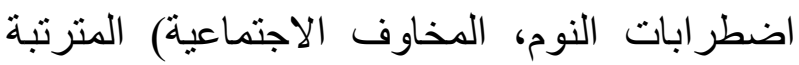
على جائحة فيروس كورونا المستجد (7) (Covid-19)، لاى عينة بلغت (746) من طلاب الجامعات الدصرية

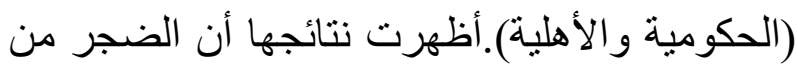
أكثر المشكلات النفسية التي يعاني منها طلاب نابه ان التهاب 
(COVID-19) و الكثف عن مستويات القلق و التوتر و الاكتئاب ومدى في التي ارتباط بعض المتغيرات بالصحة العقلية للمشاركين مثل: درجة القلق من الوباء، الظروف الييئية أثناء العزل المنزلي، التغييرات في الحباة اليومية نتيجة الوباء، مخالطة أثخاص مصابين بفيروس كورونا المستجد (COVID-19)، خطورة الأزمة الفعلية و المتصورة، والأنشطة الترفيهية التي مارسوها. وتكونت العينة من (3055) فرداً، و أظهرت النهات النتائج: أن الأزمة الصحية الحالية شديدة إلى حدٍ ما وأنها أثرت على حياة الأفر اد اليومية بشكل كبير بما في ذللك التها التغيير ات في روتينهم اليومي و إلغاء الأنشطة المهمة كما أظهرت أن النساء والأشخاص الذائ الذين فقدوا وظائفه خلال هذه الأزمة كانت لايهم الأعراض اض الثاصن النفسية السلبية أكثر من غير هم. كما أظهرت النتائنة النائج أن الأشخاص الذين مارسوا أنشطة نرفيهية أثناء العزل المنزلي و الأشخاص الذين يدركون أنهم بصحة جيدة كانوا أقل تأثراً من غير هم وصحتهم النفسية أفضل[27].

وجميع هذه الدراسات تناولت الضغوط و المشكلات الناتجة عن تأثير انتشار فيروس كورونا المستجد (COVID-19)

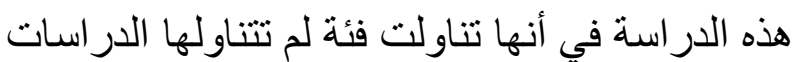
هدفت هذه الدر اسة إلى: ـ الكثف عن مستوى الضغوط النفسية الناتجة عن انتشار فيروس كورونا المستجد (Covid-19) لدى أفر اد الجالية الأردنية في حائل. ـ التعرف على مستوى الضغوط النفسية الناتجة عن انتشار فيروس كورونا المستجد (Covid-19) لاى الفى
أكثر من الذكور حيث وجد لديهن مستويات أعلى من التوتر و القلق و الاكتئاب[24]. ودر اسة أجر اها س هدفت إلى الكثف عن

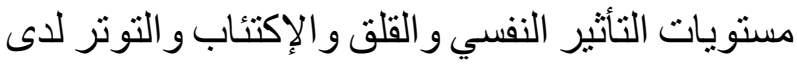
عامة السكان في الصين خلال المرحلة الأولى من COVID-) تفشي وباء فيروس كورونا المستجد فئندان 19). وتكونت العينة من (1210) فرداً من (194)

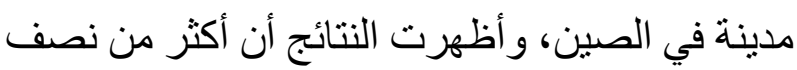
الأفر اد لديهم أعر اض شديدة إلى منوسطة من التأثير

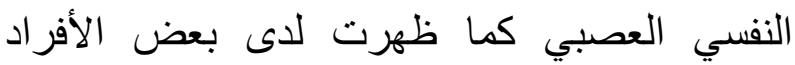
أعراض الإكتئاب والقلق ومستويات من الإجهاد بدرجة منوسطة إلى شديدة؛ ووجدت هذه الأعر اض الإس عند الإناث و الطلبة و الأفر اد الذين يعانون من ضعف

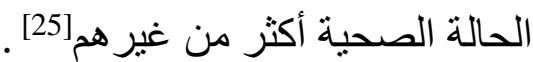
ودراسة Alvarez, Lamas, and Olmos هدفت للكثف عن مستويات الضيق النفسي و القلق و الاكتئاب والتوتر أثناء تفشي فيروس كورونا المستجد (COVID-19) (1105) فرداً من (32) و لاية في المكسيك، و أظهرت

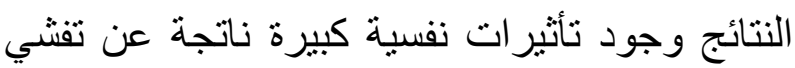
فيروس كورونا المستجد، وتضمنت هذه التأثير ات الضيق النفسي و الاكتئاب و القلق و الإجهاد و أن الإناث

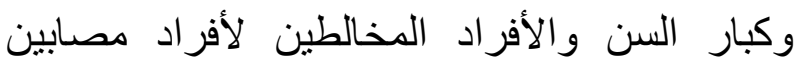

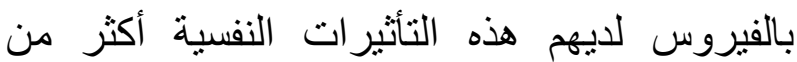
غيرهم، كما أظهرت النتائج أن الأفر اد الذين بتخذون الفئن

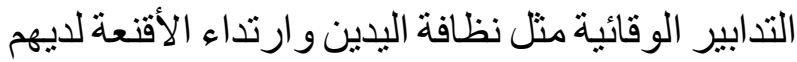

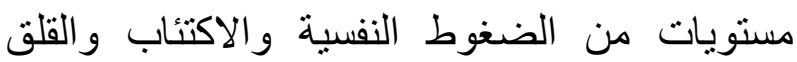
و التوتر أقل مما لدى غير هم [26]. ودراسة Hernansaiz, and Collado هدفت للكثف عن التأثير النفسي والعوامل المصاحبة له خلال المرحلة الأولية لوباء فيروس كورونا المستجد 
أهمبة البحث:

الأهمية النظرية: تنمثل الأهمية النظرية لهذه الار اسة فيما تقدمه من إضافة علمية حول علاقة انتشار فيروس كورونا المستجد (Covid-19) بالضغوط النفسية لدى الأفر اد كما تأتي أهمية هذه الدراسة في

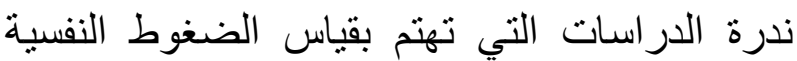
الناتجة عن انتشار فيروس كورونا لدى هذه الفئة و عدم توفر ها على حد علم الباحثة الأهمية التطبيقية: تأتي أهمية الدراسة التطبيقية في

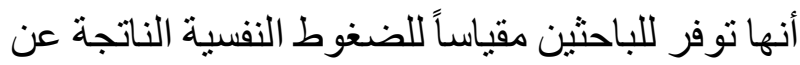
انتشار فيروس كورونا المستجد (Covid-19)، كما يمكن للعاملين في مجال الارشاد النفسي والأسري الاستفادة من نتائج هذه الدر اسة في تفعيل وتقديم بر امج الارشاد النفسي للمساهمة في تخفيف مستوى الضنوط هذه النفسية لاى أفراد الجالية الأردنية في حائل وتجديد النشاط و الحيوية لديهم. حدود البحث: الحدود الزمنية: تم تطبيق الدراسة خلابل القترة 2020/6/4 م إلى 2020/6/11 الحدود المكانية: تم تطبيق الدر اسة في وسط حائل في المملكة العربية السعودية. الحدود البشرية: تم تطبيق الدراسة على الفية أفر اد الجالية

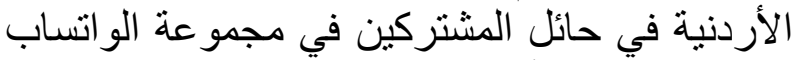

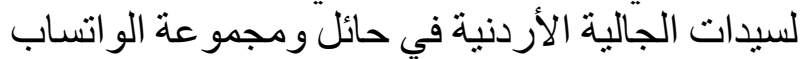
لرجال الجالية الأردنية في حائل. التعريف بالمصطلحات:

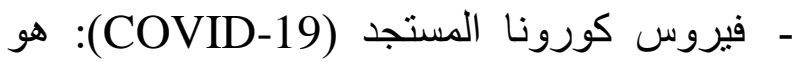
فيروس يرنبط بعائلة فيروسات كورونا التي ينتمي

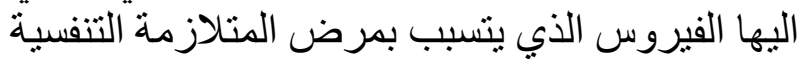

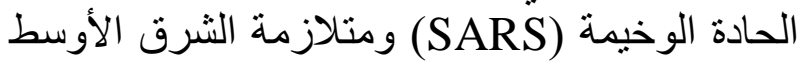

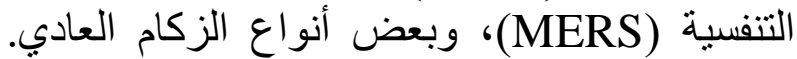

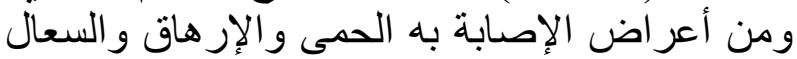

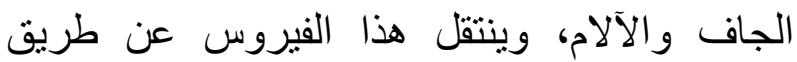

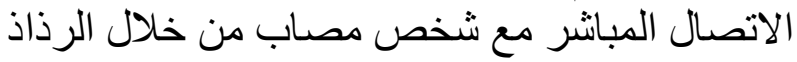

أفر اد الجالية الأردنية في حائل في ضوء المتغير ات (النوع الاجتماعي، والحالة الاجتماعية، و وعدد

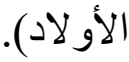

مشكلة البحث: الأد:

جاءت ملاحظة الباحثة و إحساسها بمشكلة الدر اسة من طبيعة تواجدها في مجتمع الدراسة وادر اكها لوجود ضغوط نفسية ناتجة عن انتشار فيروس كورونا المستجد (COVID-19)، ولأن الضغوط النوط النفسية

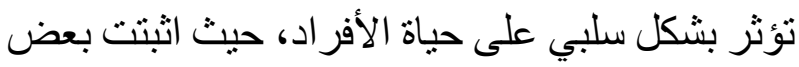

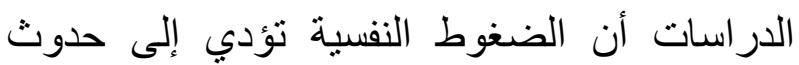
الجلطات القلبية منل دراسة حمودة وزملاؤ Hammoudeh et al الجلطة القلبية الحادة لدى افراد العينة نتجت عن الضغوط النفسية الناتجة عن انتشار فيروس كورونا المستجد(COVID-19).

ومن هنا جاءت ضرورة الكثف عن مستوى الضغوط النفسية لاى أفر اد الجالية الأردنية في حائل، وتحديداً جاءت هذه الدراسة للإجابة عن الأسئلة التالية:

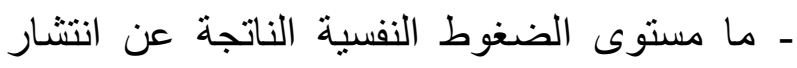
فيروس كورونا المستجد (COVID-19) لدى أفر اد الجالية الأردنية في حائل على الأداة ككل وفي كل مجال من مجالاتها؟ - هل هناك فروق ذات دلالة إحصائية عند مستوى هئل الدلالة (م=0.05) في المجالات الرئيسية لمقياس الضغوط النفسية تعزى لمتغير النوع الاجتماعي؟ - هل هناك فروق ذات دلالة إحصائية عند مستوى الدلالة (0.05) في المجالات الرئيسية لمقياس

الضغوط النفسية تعزى لمتغير الحالة الاجتماعية؟ - هل هناك فروق ذات دلالة إحصائية عند مستوى الدلالة (1)=0.05) في المجالات الرئيسية لمقياس

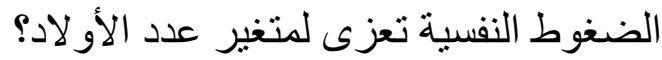


منهجية البحث:

اعتمدت الباحثة في هذه الدئة الدراسة على المنهج الوصفي لمناسبته لأهداف الذار اسة وأسئلتها.

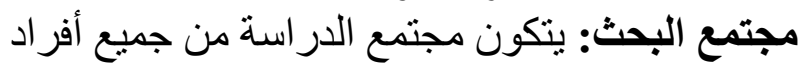

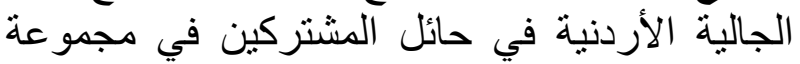

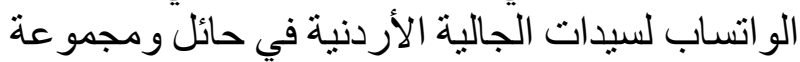
الواتساب لرجال الجالية الأردنية في حائل، البالغ الغية عددهم 271 فرداً. عينة البحث: تم اختيار العينة بالطريقة المتيسرة

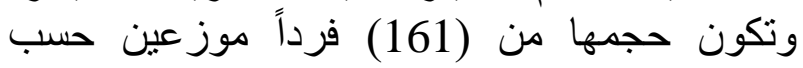
متغيرات الدراسة كما هو موضح في الجدول رقم

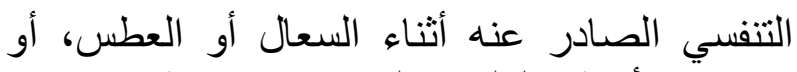

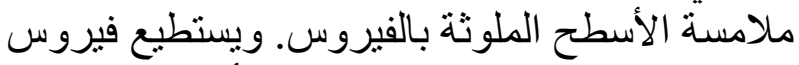

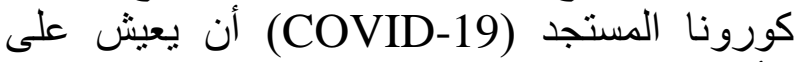

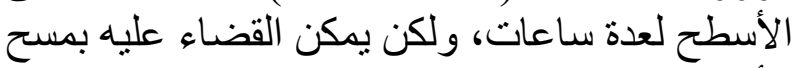

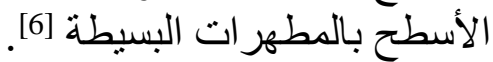

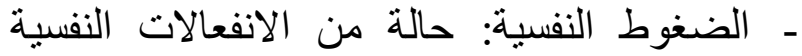

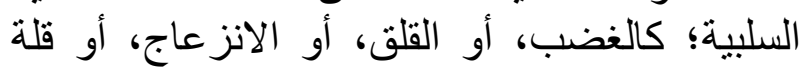

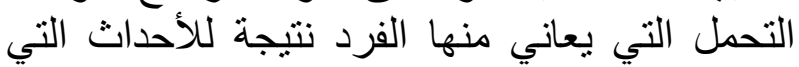
تهدده أو تتحداه بجميع فعاليات الحياة [19]. - تعرف الباحثة الضغوط النفسية إجرائياً: بأنها

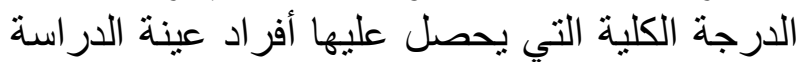
على مقياس الضغوط النفسية المستخدم في الدراسة النة النة

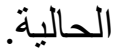

جدول (1) التكرارات والنسب المئوية حسب متغيرات الدراسة

\begin{tabular}{|c|c|c|c|}
\hline النسبة & الأنكرار & الفئات & \multirow{3}{*}{ النوع الاجتماعي } \\
\hline 42.2 & 68 & ذكر | (ذر & \\
\hline 57.8 & 93 & 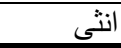 & \\
\hline 85.1 & 137 & متزوج & \multirow[t]{2}{*}{ الحالة الاجتماعية } \\
\hline 14.9 & 24 & اعزب & \\
\hline 16.8 & 27 & لا يوجد & \multirow[t]{3}{*}{ الأبناء } \\
\hline 74.5 & 120 & من 5-1 5 5 5 & \\
\hline 8.7 & 14 & من & \\
\hline 100.0 & 161 & المجموع & \\
\hline
\end{tabular}

ومدى سلامة صياغتها وتمثيلها للمجال المطلوب. وحظيت الفقرات بمو افقة (80\%) من المحكمين. وللتحقق من ثبات المقياس فقد تم التحقق بطريقة

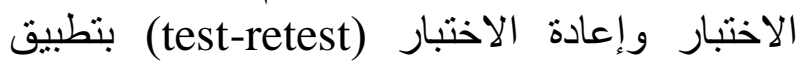

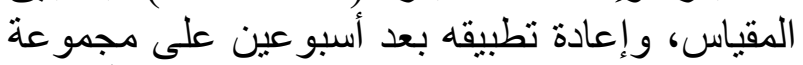

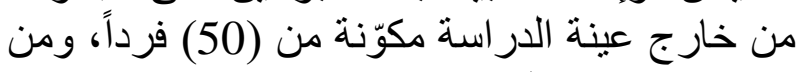

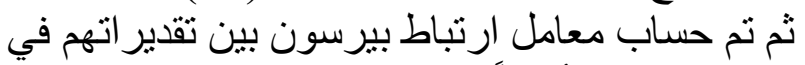

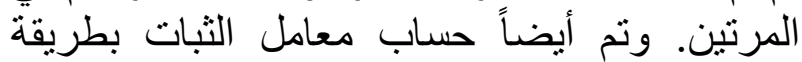
الاتساق الداخلي حسب معادلة كرونباخ ألفا، و الجدول

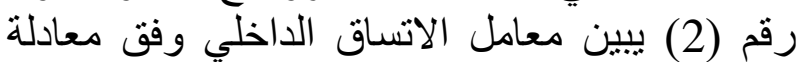
كرونباخ ألفا وثبات الإعادة للمجالات الات والألي الاداة ككل
أداة البحث: بعد الاطلاع على الأدب النظري المتعلق

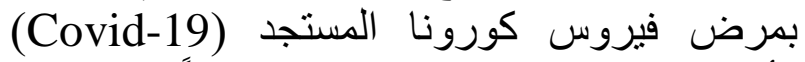

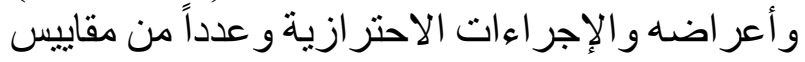

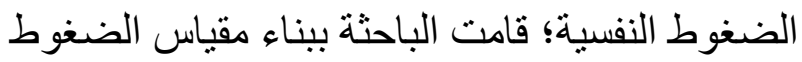

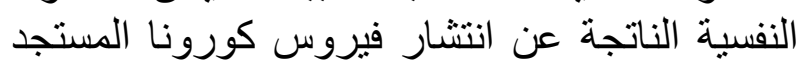

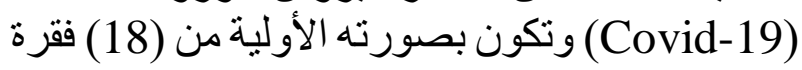
موز عة على مجالين: الجسدي و النفسي.

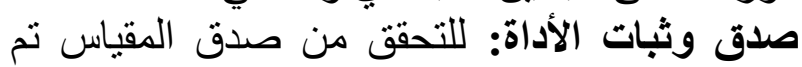

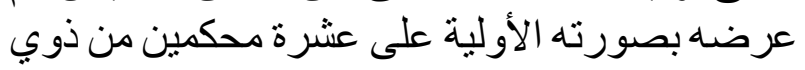

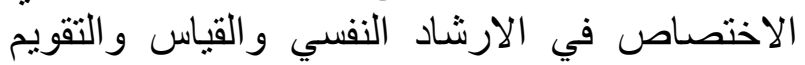
لإبداء آر ائهم حول مناسبة وانتماء الفقر اتل للمجالات الفات

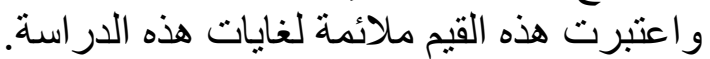

جدول (2) معامل الاتساق الداخلي كرونباخ ألفا وثبات الإعادة للمجالات والإرجة الكلية

\begin{tabular}{|c|c|c|}
\hline الاتساق الداخلي & ثُبات الإعادة & المجال \\
\hline 0.74 & 0.91 & الجانب الجسدي \\
\hline 0.85 & 0.89 & الجانب النفسي \\
\hline
\end{tabular}




\begin{tabular}{|l|r|r|}
\hline 0.87 & 0.92 & الدرجة الكلية \\
\hline
\end{tabular}

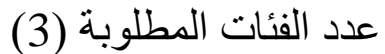
5- 1 = 1.33 و من ثم إضافة الجواب (3) (1.33) إلى نهاية كل فئة.

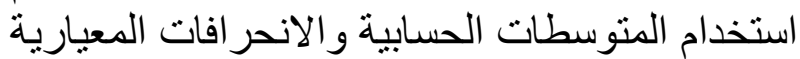

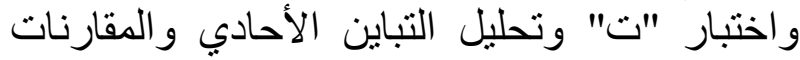
البعدية بطريقة شفيه. عرض النتائج ومناقشتها: السؤال الأول: ما مستوى الضغنوف الضونها: النفسية الناتجة

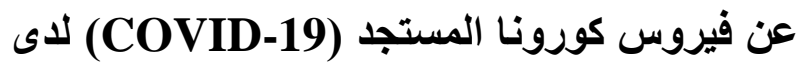
أفراد الجالية الأردنية في حائل على الأداة ككل وفي كل مجال من مجالاتها؟

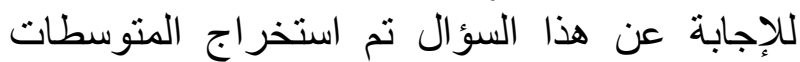

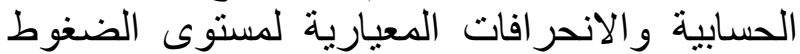
(COVID-19) لاى أفر اد الجالية الأردنية في حائل فئل على الأداة ككل وفي كل مجال من مجالاتها، و الجدول (3) يوضح ذللك. الأسـاليب الإحصائية: للإجابة عن أسئلة الدراسة تم

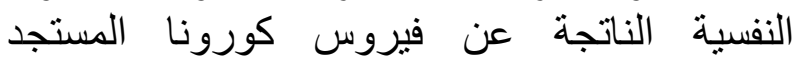

تصحيح المقياس: تم اعتماد سلم ليكرت الخماسي لتصحيح أدوات الدر اسة، بإعطاء كل فقرة من فقر اته درجة واحدة من بين درجاته الخمس (دائماً /غالباً /

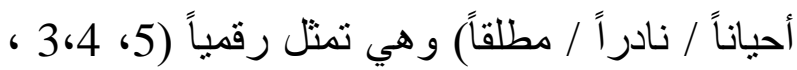
2، 1 ) على الترتيب، حيث نزاوحت الدرجات التي يمكن ان يحصل عليها المستجيب بين (18 -90) درجة، ولتفسير الدرجة التي يمكن أن يحصل عليها المستجيب يتم احتساب المتوسط الحسابي كالآتي: الدرجة الكلية التي حصل عليها المستجيب عدد فقرات المقياس وقد تم اعتماد المعيار التالي للحكم على مستوى الضغوط النفسية لأغر اض تحليل النتائج: من (1.002.33) قليلة. من (2.34- 3.67) متوسطة. من (3.68) - 5.00) كبيرة وقد تم احتساب المقياس من خلال استخدام المعادلة التالية: الحد الأعلى للمقياس (5) - الحد الأدنى للمقياس(1) المعادلة

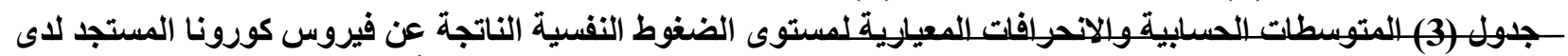

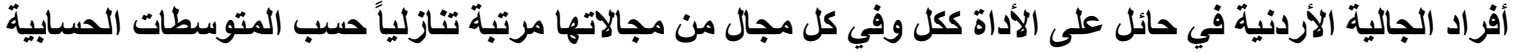

\begin{tabular}{|c|c|c|c|c|c|}
\hline المستوى & الانحر اف المعياري & المتوسط الحسابي & 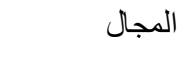 & 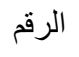 & الرتبة \\
\hline متوسط & .799 & 3.65 & الجانب النفسي & 2 & 1 \\
\hline متوسط & .762 & 2.95 & الجانب الجسدي & 1 & 2 \\
\hline متوسط & .711 & 3.34 & الدرجة الكلية & & \\
\hline
\end{tabular}

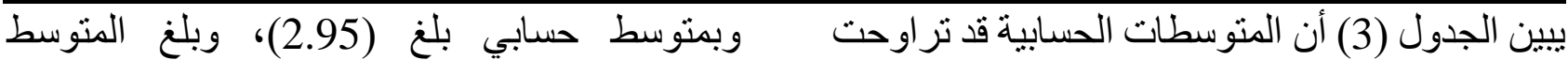
الحسابي للأداة ككل (3.34).

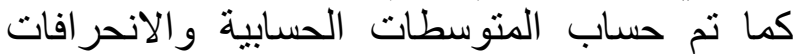

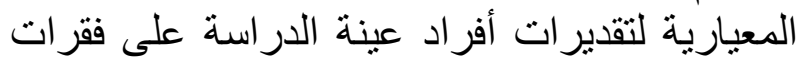
كل مجال على حدة، حيث كانت على النحو التالي: ما بين (3.65-2.95)، حيث جاء الجانب النفسي في التئي المرتبة الأولى بأعلى متوسط حسابي بلغ (3.65)، بينما جاء الجانب الجسدي في المرتبة الأخيرة المجال الأول: الجانب الجسدي جذول (4) المتوسطات الحسابية والأنحرافات المعيارية المتعلقة بالجانب الجسدي مرتبة تنازلياً حسب المتوسطات الحسابية

\begin{tabular}{|c|c|c|c|c|c|}
\hline المستوى & الانحر اف المعياري & المتوسط الحسابي & الفقرات & الرقم & الرتبة \\
\hline 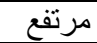 & 1.217 & 3.93 & بر هقني جدأ تعقيم المشتريات. & 2 & 1 \\
\hline متوسط & 1.317 & 3.44 & أعاني من اضطر اب في النوم. & 6 & 2 \\
\hline 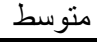 & 1.079 & 3.07 & أشُعر بانخفاض في طاقتي. & 8 & 3 \\
\hline
\end{tabular}




\begin{tabular}{|c|c|c|c|c|c|}
\hline 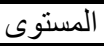 & الانحر اف المعياري & المتوسط الحسابي & 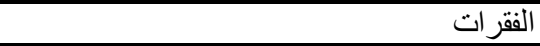 & الرقم & الرتبة \\
\hline 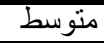 & 1.440 & 2.98 & تر هقني رعاية أفر اد الأسرة وتخفيف الملل عنهم. & 5 & 4 \\
\hline 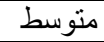 & 1.049 & 2.70 & اشتعر بالتعب و الإرهاق عند القيام بأبسط الأعمال. & 1 & 5 \\
\hline 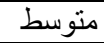 & 1.492 & 2.50 & تر هقني جداً متابعة دروس أبنائي. & 4 & 6 \\
\hline متوسط & 1.256 & 2.48 & ير هقني إنجاز العمل عن بعد ـ الكترونياً. & 3 & 7 \\
\hline متوسط & 1.285 & 2.48 & يصبني شد عضلي في الرقبة. & 7 & 7 \\
\hline 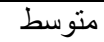 & .762 & 2.95 & الجانب الجسدي & & \\
\hline
\end{tabular}

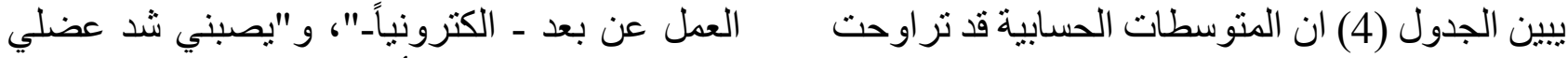

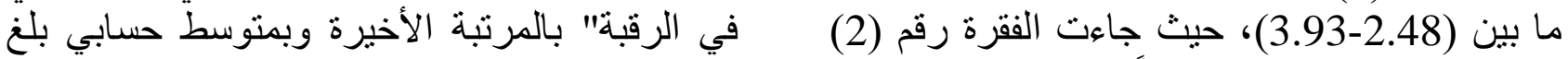
(2.48). وبلغ المتوسط الحسابي للجانب الجسدي ككل الجني

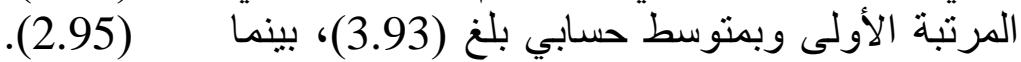
جاءت الفقرتان رقم (3 و 7) ونصوهما "ير هقني إنجاز (3.

\begin{tabular}{|c|c|c|c|c|c|}
\hline 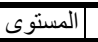 & الانحر اف المعياري & | - المتوسط الحسابي & 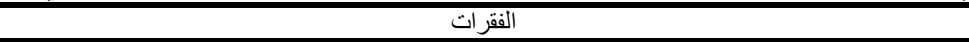 & |الرقق & الرتبة \\
\hline |مرتفع & .974 & 4.45 & أتضايق لعدم قدرتي على السفر لرؤية الالهل و الآحبة. & 18 & 1 \\
\hline 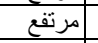 & 1.056 & 4.39 & أشعر بالثوق و الحنين للوطن. & 16 & 2 \\
\hline مرتفع & 1.124 & 4.20 & 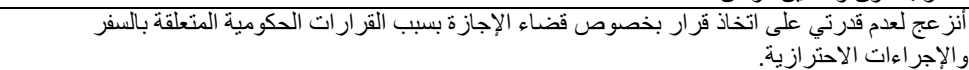 & 17 & 3 \\
\hline 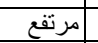 & 1.310 & 3.77 & بقلقني احتمالية إصابة أحد أفر اد أسرتي بفيروس كورونا المستجد (COVID-19). & 10 & 4 \\
\hline متوسط & 1.273 & 3.64 & أنضايق لعدم قدرتي أنا و أفر اد أسرتي على الذهاب إلى الأماكن الترف فيهية. & 15 & 5 \\
\hline متوسط & 1.294 & 3.53 & الألفواقي بنفساط العدوى بفيروس كورونا المستجد (COVID-19) عندما أقوم بثأمين حاجات ومتطلبات الأسرة من & 9 & 6 \\
\hline متوسط & 1.423 & 3.45 & يخيفني التفكبرِ في أن مناعة أفر اد أسرتي قد نكون ضعيفة. & 11 & 7 \\
\hline مثوسط & 1.228 & 3.43 & أثشعر بالضيق بسبب التباعد الاجتماعي. & 14 & 8 \\
\hline متوسط & 1.140 & 3.18 & أبسط الأهور تشتئر غضبي. & 12 & 9 \\
\hline متوسط & 1.236 & 2.49 & ظظهرت المشاكل الأسرية بسبب بقاء أفر اد الأسرة مع بعضهم لفترة طويلة. & 13 & 10 \\
\hline متوسط & .799 & 3.65 & الجانب النفسي & & \\
\hline
\end{tabular}

الجانب النفسي في المرتبة الأولى بأعلى متوسط

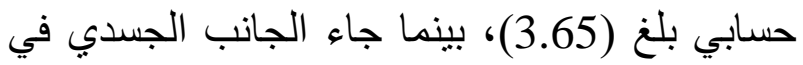
المرتبة الأخيرة وبمتوسط حسابي بلغ (2.95)، وبلغ المتوسط الحسابي للأداة ككل (3.34). وقد يعزى ذللك COVID-) إلى أن انتشار فيروس كورونا المستجدابط

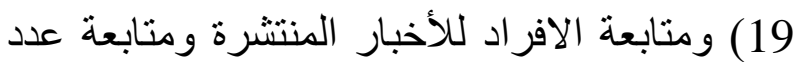
الإصـابات اليومية وسر عة انتشار الفيروس أدى إلى الى إدر اكهم لوجود بعض الخطر المحيط بهم مما أدى إلى وجود بعض القلق والتونز لايهم وظهور مستوى متوسط من الضغوط النفسية وهذا يتفق مع ما ذكرته السكافي [3] بخصوص أن إدر اك الافر اد للمخاطر قد مد مانع يعرضهم لضغوط نفسية خاصة أثناء تواجدهم في الحجر الصحي المنزلي المفروض عليهم. كما أن
يبين الجدول (5) ان المتوسطات الحسابية قد تراوحت ما بين (2.49-4.45)، حيث جاءت الفقرة رقم (18) و التي تنص على "أتضايق لعدم قدرتي على السفر

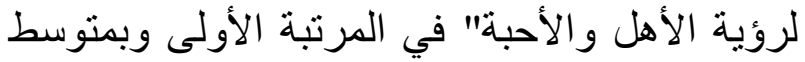
حسابي بلغ (4.45)، بينما جاءت الفقرة رقم (13) ونصها "ظهرت المشاكل الأسرية بسبب بقاء أفراد اد بله الأسرة مع بعضهم لفترة طويلة" بالمرتبة الأخيرة وبمتوسط حسابي بلغ (2.49). وبلغ المتوسط الحسابي للجانب النفسي ككل (3.65). يتضح من عرض النتائج وجود مستوى منوسط من الضغوط النفسية الناتجة عن فيروس كورونا المستجد لادى أفر اد الجالية الأردنية في حائل (COVID-19) على الأداة ككل وفي كل مجال من مجالاتها، وجاء 
"وبمتوسط حسابي مرتفع بلغ (COVID-19)

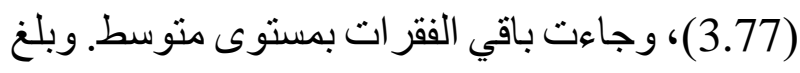
المتوسط الحسابي للجانب النفسي ككل (3.65) (3.65).

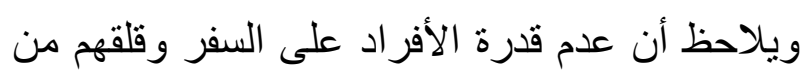

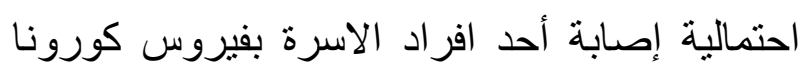

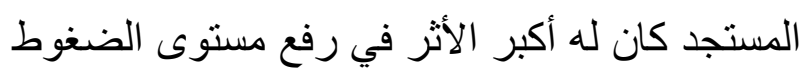
في الجانب النفسي أكثر منه في الجانب الجسدي.

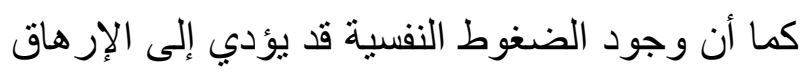

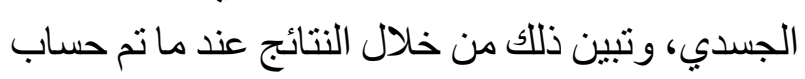

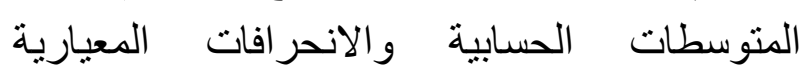
لتقدير ات أفراد عينة الدراسة على الفقرات المتعلقة بالجانب الجسدي، فقد تراوحت المتوسطات الحسابية

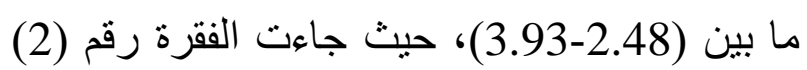

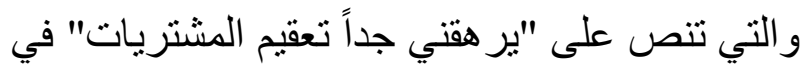

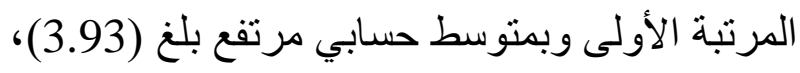

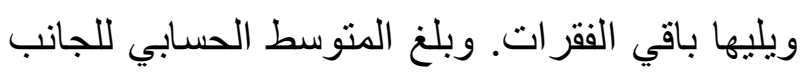

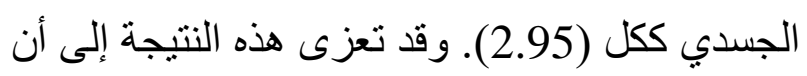

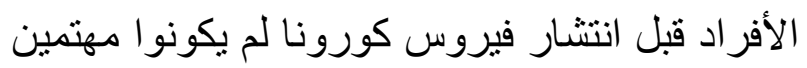

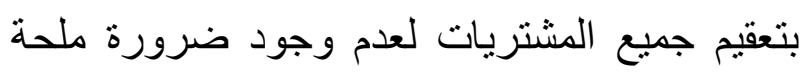

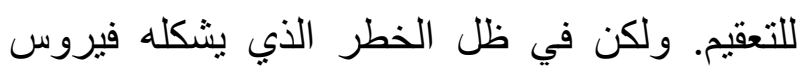

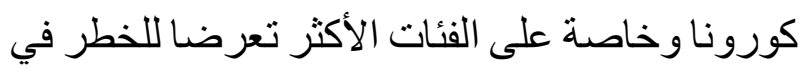

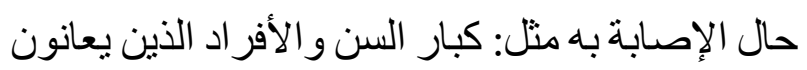

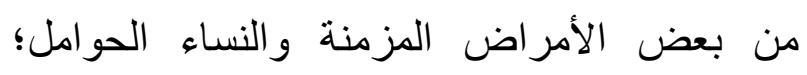

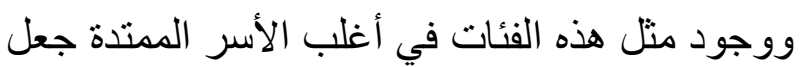

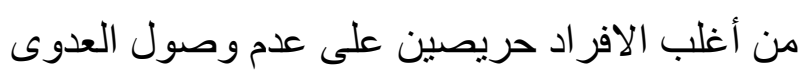

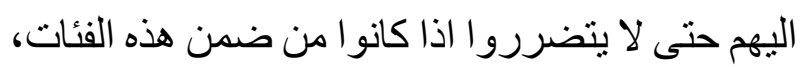

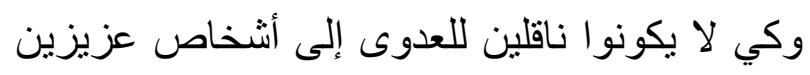
عليهم وخاصة أن أغلب أفراد الجالية الأردنية لإنية ير غبون ويخططون للعودة إلى وطنهم الأردن خلال

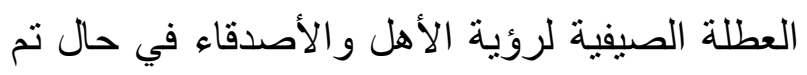

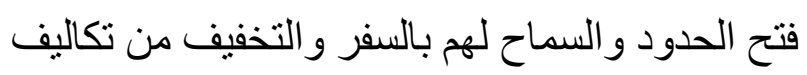

فرض الإجراءات الاحترازية في المملكة العربية

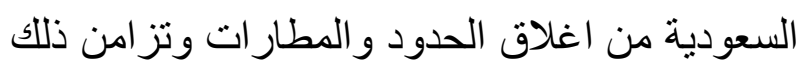

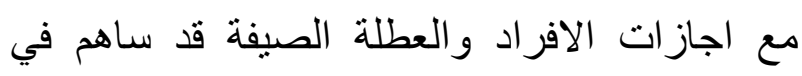

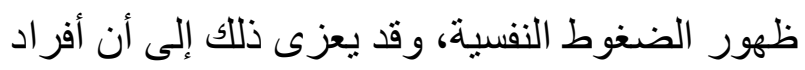

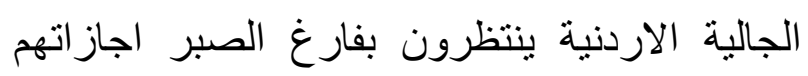

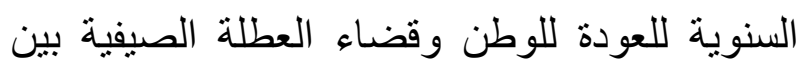

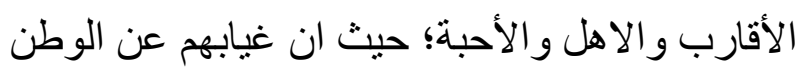

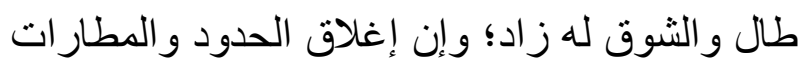

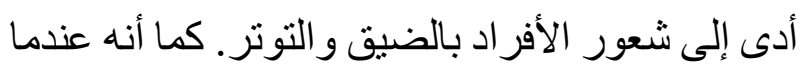

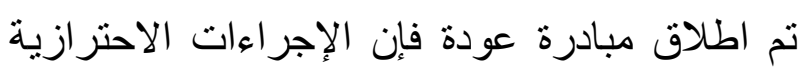

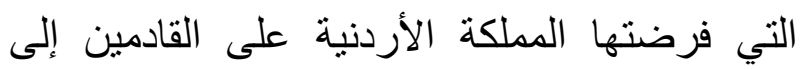

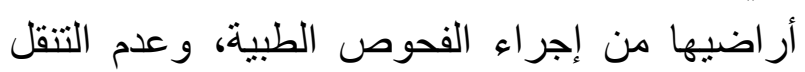
بالسيارة الخاصة بالأفر اد؛ و انما الانتقال الى مناطق وعن الحنق

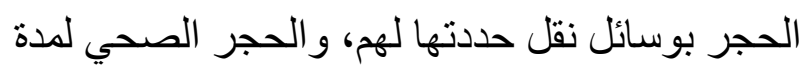

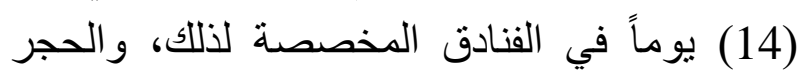

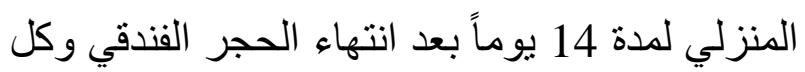

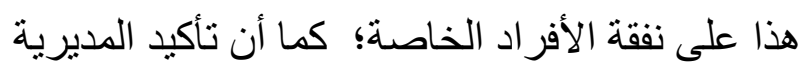

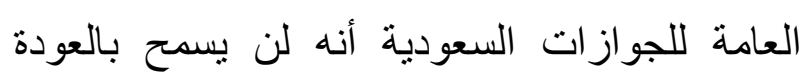

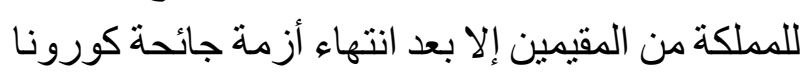

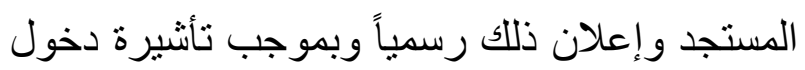

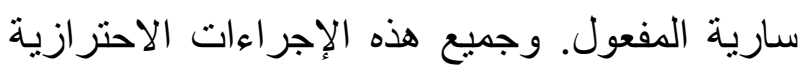

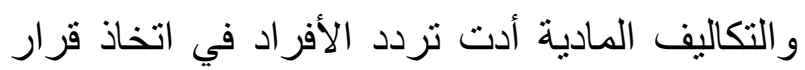
العودة للوطن كل ذللك كان له الأثر الكبير في رفع الكاد فئ

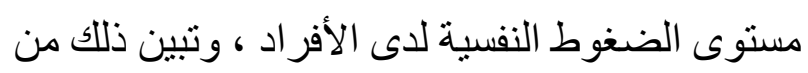
خلال النتائج عند ما تم حساب المتوسطات الحسابية

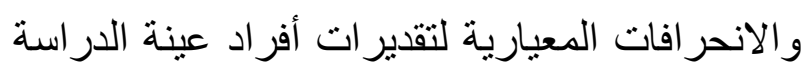

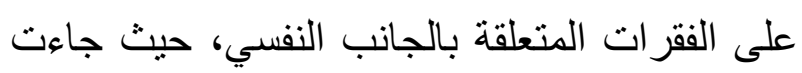
الفقرات (18،18،16 ) بمتوسطات حسابية مرتفعة باتل وكانت تتعلق بالانز عاج لعدم القدرة على السفر ثم جاءت الفقرة (10) وتنص على " يقلقني احتمالية إصابة أحد أفراد أسرتي بفيروس كورونا المستجد 
ومستويات من الضيق النفسي الإجهاد و القلق و التوثر أثناء تفشي فيروس كورونا المستجد (COVID-19) بدرجة متوسطة إلى شديدة. السؤال الثاني: هل هنالك فروق ذات دلائة إحصائية

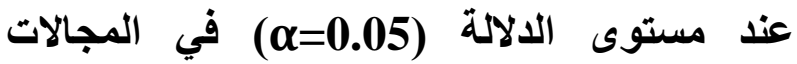
الرئيسية لمقياس الضغوط النفسية تعزى لمتغير النوع الاجتماعي? للإجابة عن هذا السؤال تم استخراج المتوسطات الحسابية والانحر افات المعيارية لمقياس الضغوط النفسية حسب متغير النوع الاجتماعي، ولبيان الفروق الإحصائية بين المتوسطات الحسابية تم استخدام اختبار "ت"، و الجدول (6) يوضح ذلك.
الإجراءات الاحترازية . و وإن وجود أفراد الأسرة في حيز واحد وهو المنزل أثناء فترة الحظر وفرض التباعد الاجتماعي واغلاق الأماكن الترفيهية واغلاق المساجد ومنع التواجد في الحدائق العامة ، و القيام بإنجاز العمل عن بعد، ومتابعة دراسة الأبناء بعد اغلاق المدارس كل ذلك كان له أثره في تسلل الملل الى نفوس الأفر اد، وحدوث بعض الاضطر ابات في النوم و الثعور بالتعب والارهاق عند القيام بأبسط الأعمال و وانخفاض الطاقة لدى الافراد، وبالتالي حدوث بعض الإحباط الذي يكلف بعض الجها في التخفيف منه في محاولة منع حدوث المشاكل الأسرية لهنية و هذا أدى إلى وجود مستوى متوسط من الضغوط في

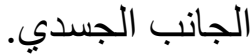

وتتفق هذه النتيجة مع در اسة الفقي وأبو الفتوح [23] ودراسة ول Hammoudeh et al. [24 Mustafa [26] Alvarez, Lamas, and Olmos مey, Hernansaiz, and Collado وجود بعض المشكلات التي نتجت عن انتشار فيروس كورونا بدرجة منوسطة. وارتفاع مستوى الضغوط

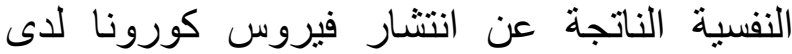

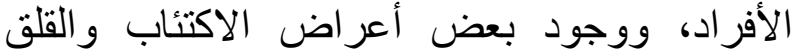
جدول (6) المتوسطات الحسابية والانحر افات المعيارية واختبار "تأل لأثر النوع الاجتماعي على مقياس الضغوط النفسية

\begin{tabular}{|c|c|c|c|c|c|c|c|}
\hline الدلالة الإحصائية & درجرية & قيمة "ت" & الانحر اف المعياري & المتوسط الحسابي & 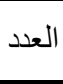 & النوع الاجتماعي & \\
\hline \multirow[t]{2}{*}{.024} & \multirow[t]{2}{*}{159} & \multirow[t]{2}{*}{-2.278} & .770 & 2.79 & 68 & ذكر & الجانب \\
\hline & & & .738 & 3.06 & 93 & أنثى & الجسدي \\
\hline \multirow[t]{2}{*}{.000 } & \multirow[t]{2}{*}{159} & \multirow[t]{2}{*}{-4.591} & .806 & 3.34 & 68 & ذكر & الجانب \\
\hline & & & .712 & 3.89 & 93 & أنثى & النفسي \\
\hline \multirow[t]{2}{*}{.000} & \multirow[t]{2}{*}{159} & \multirow[t]{2}{*}{-3.940} & .733 & 3.09 & 68 & ذكر & الدرجة \\
\hline & & & .640 & 3.52 & 93 & أنثى & الكلية \\
\hline
\end{tabular}

يتبين من الجدول (6) وجود فروق ذات دلالة النوع الاجتماعي في جميع المجالات وفي الدرجة إحصائية عند مستوى الدلالة (0.05) تعزى لأثر الكلية وجاءت الفروق لصالح الإناث. 


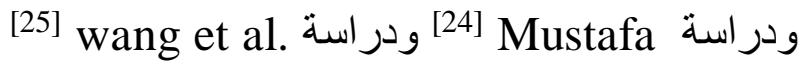
ودراسة Alvarez, Lamas, and Olmos حيث أن الارتفاع في مستوى الضغوط النفسية لدى

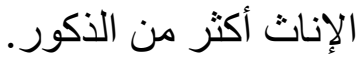

السؤال الثالث: هل هناك فرك فروق ذات دلاتلة إحصائية

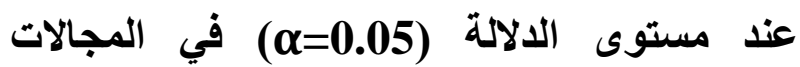
الرئيسية لمقياس الضغوط النفسية تعزى لمتغير الحالة الاجتماعية؟ الميائ

للإجابة عن هذا السؤال تم استخر اج المتوسطات الحسابية والانحرافات المعيارية لمقياس الضغوط النفسية حسب متغير الحالة الاجتماعية، ولبيان الفروق الإحصائية بين المتوسطات الحسابية تم استخدام

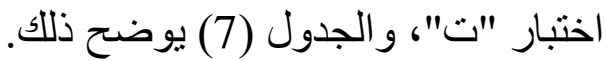

وقد تعزى هذه النتيجة إلى أن الإناث عاطفيات أكثر من الذكور فتتور لايهن مشاعر الثوق والحنين إلى الثى الأهل، ويفكرن في افراد الأسرة؛ كما يزداد قلقهن

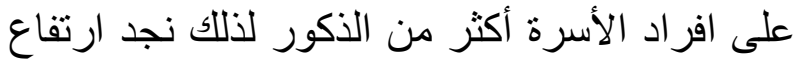

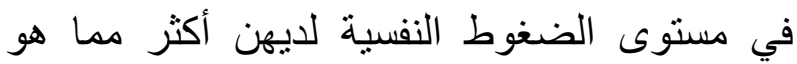

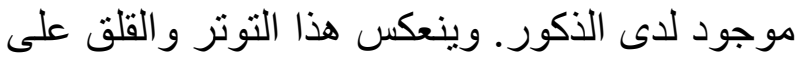
الجانب الجسدي أيضا فتظهر بعض اضطر لإن ابات النوم ويظهر الإرهاق والتعب بالإضافة إلى الدور المعتاد

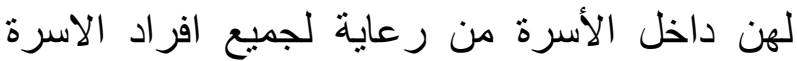

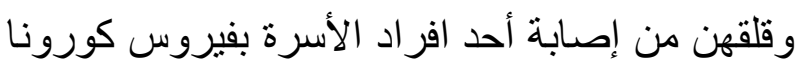
المستجد مما يؤدي الى زيادة الاهتمام بتعقيم

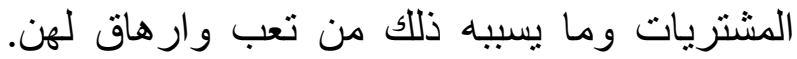

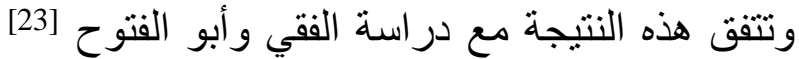

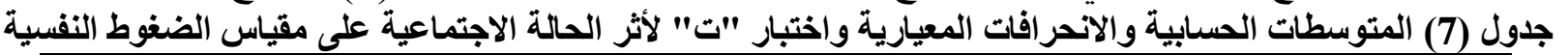

\begin{tabular}{|c|c|c|c|c|c|c|c|}
\hline الدلالة الإحصائية & درجات & "تيمة & الانحر اف المعياري & المتوسط الحسابي & العدد & الحالة الاجتماعية & \\
\hline \multirow[t]{2}{*}{.006} & \multirow[t]{2}{*}{159} & \multirow[t]{2}{*}{2.808} & 741 & 3.02 & 137 & متزوج & \multirow{2}{*}{ الجسدبي } \\
\hline & & & .773 & 2.55 & 24 & غير ذلك & \\
\hline \multirow[t]{2}{*}{.091} & \multirow[t]{2}{*}{159} & \multirow[t]{2}{*}{1.698} & .778 & 3.70 & 137 & متزوج & \multirow{2}{*}{ النفسي } \\
\hline & & & .887 & 3.40 & 24 & غير ذلك & \\
\hline \multirow[t]{2}{*}{.018} & \multirow[t]{2}{*}{159} & \multirow[t]{2}{*}{2.398} & .688 & 3.39 & 137 & متزوج & \multirow{2}{*}{ الكلية } \\
\hline & & & .772 & 3.02 & 24 & غير ذلك & \\
\hline
\end{tabular}

مدى التفاعل سواء الإيجابي أو السلبي الذي قد يجعل

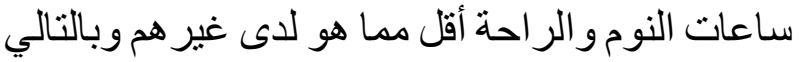
يظهر التعب والارهاق لديهم أكثر من غير هم. وتتفق

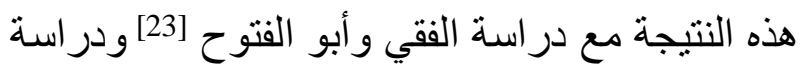
[24] Mustafa Hammoudeh et al.

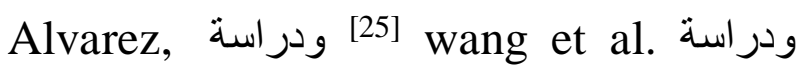
Rey, ودراسة 26 Lamas, and Olmos من Hernansaiz, and Collado مستوى متوسط من الضغوط الناتجة عن انتشار

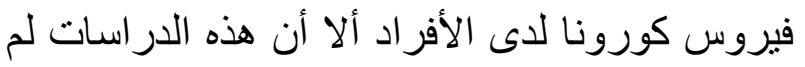

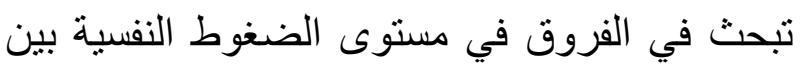

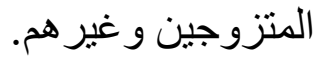

يتبين من الجدول (7) وجود فروق ذات دلالة

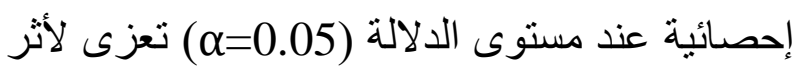
الحالة الاجنماعية في الجانب الجسدي وفي الدرجة الإنة

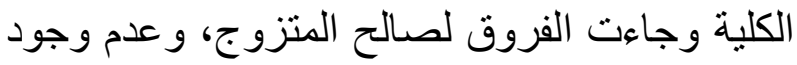
فروق ذات دلالة إحصائية عند مستوى الدالية

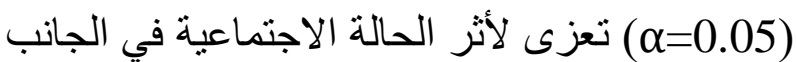
النفسي. وقد تعزى هذه النتيجة إلى أن المتزوجين لديهم مسؤوليات أكثر تجاه افراد الأسرة حيث يكون عدد الفي الفئ أفر اد الأسرة لايهم أكثر من غير هم فتزيد المسؤوليات سواء من الاهتمام بكل فرد فيها وتلبية طلباته وحاجاته، أو كمية المشتريات التي تحتاج للتعقيم، أو الو فله 


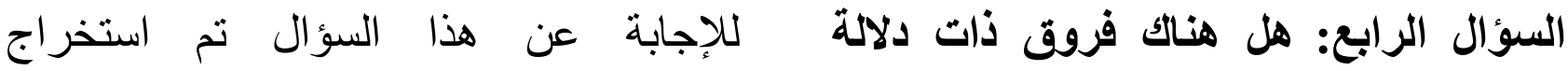
المتوسطات الحسابية والانحر افات المعيارية

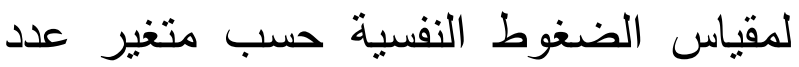

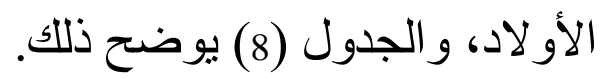

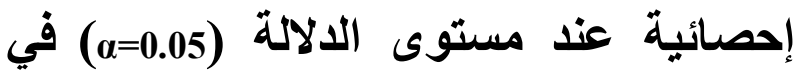

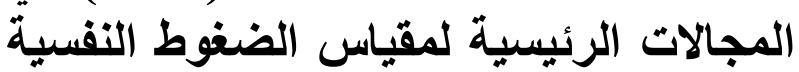
تعزى لمتغير عدد الأولاد؟ جدول (8) المتوسطات الحسابية والانحر افات المعيارية لمقياس الضغوط النفية حسب متغير عدد الأولاد

\begin{tabular}{|c|c|c|c|c|}
\hline الانحر اف المعياري & المتوسط الحسابي & 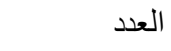 & الفئات & \\
\hline .690 & 2.52 & 27 & لا يوجد & \multirow[t]{4}{*}{ الجانب الجسدي } \\
\hline .752 & 3.03 & 120 & من 1-5 & \\
\hline .748 & 3.01 & 14 & من 6-10 & \\
\hline .762 & 2.95 & 161 & المجموع & \\
\hline .859 & 3.33 & 27 & لا يوجد & \multirow[t]{4}{*}{ الجانب النفسي } \\
\hline .778 & 3.72 & 120 & من 1-5 & \\
\hline .762 & 3.67 & 14 & من 6-10 & \\
\hline .799 & 3.65 & 161 & المجموع & \\
\hline .712 & 2.97 & 27 & لا يوجد & \multirow[t]{4}{*}{ الدرجة الكلية } \\
\hline .695 & 3.42 & 120 & من 1-5 & \\
\hline .675 & 3.38 & 14 & من 6-10 & \\
\hline .711 & 3.34 & 161 & المجموع & \\
\hline
\end{tabular}

دلالة الفروق الإحصائية بين المتوسطات الحسابية

يبين الجدول (8) تبايناً ظاهرياً في المنوسطات استخدم تحليل التباين الأحادي حسب لالجين الجدول (9).

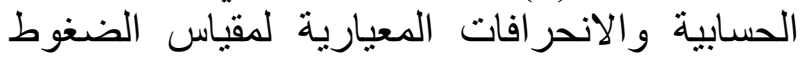

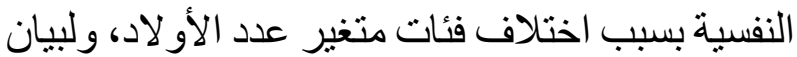

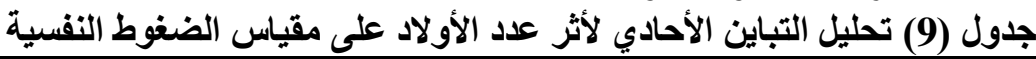

\begin{tabular}{|c|c|c|c|c|c|c|}
\hline الدلالة الإحصائية & ققيمة ف & متوسط المربعات & درجات الحرية & مجموع المربعات & المصدر & \\
\hline .006 & 5.286 & $\begin{array}{c}2.910 \\
.551\end{array}$ & $\begin{array}{c}2 \\
158 \\
160\end{array}$ & $\begin{array}{c}5.820 \\
86.983 \\
92.804 \\
\end{array}$ & داخل المجموعات الكموات & الجانب الجسدي \\
\hline .071 & 2.696 & $\begin{array}{c}1.686 \\
.625\end{array}$ & $\begin{array}{c}2 \\
158 \\
160\end{array}$ & $\begin{array}{c}3.371 \\
98.808 \\
102.180\end{array}$ & داخل المجموعات الكموات & الجانب النفسي \\
\hline .012 & 4.515 & $\begin{array}{c}2.187 \\
.484\end{array}$ & $\begin{array}{c}2 \\
158 \\
160\end{array}$ & $\begin{array}{c}4.373 \\
76.516 \\
80.889\end{array}$ & داخل المجموعات المجموت & الدرجة الكلية \\
\hline
\end{tabular}

الزوجية الدالة إحصائيا بين المتوسطات الحسابية تم استخدام المقارنات البعدية بطريقة شفيه كما هو مبين الجين في الجدول (10).
يتبين من الجدول (9) وجود فروق ذات دلالة

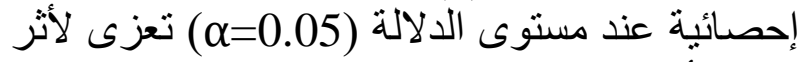

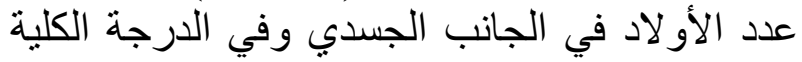

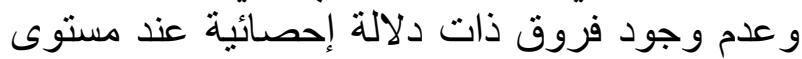

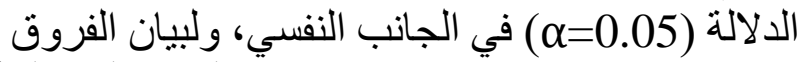

جدول (10) المقارنات البعدية بطريقة شفية لأثر عدد الأولاد على الجاتب الجسدي والدرجة الكلية

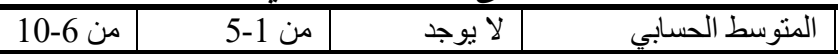




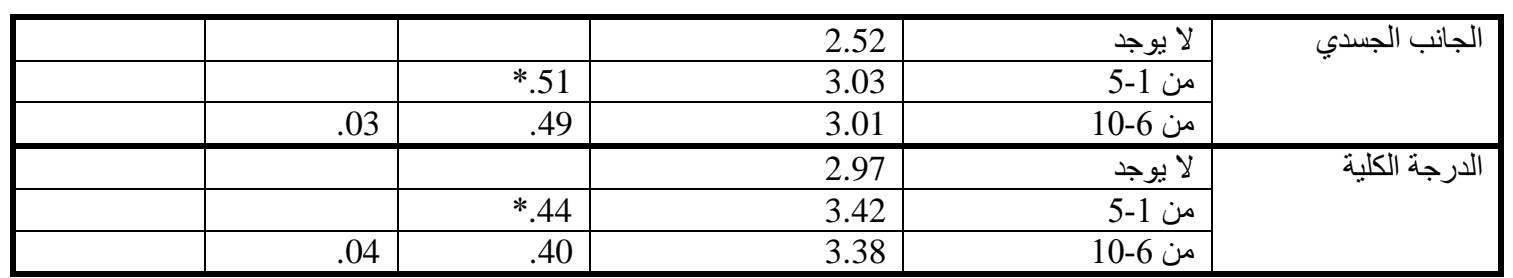
*دالة عند مستوى الدلالة (1) (م=05) - إجر اء المزيد من البحوث حول تأثير انتشار الوباء

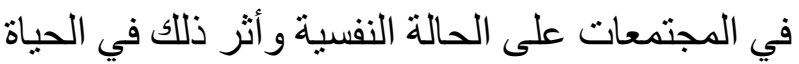
اليومية والأسرية والأداء المهني والإنجاز في العمل. المراجع

1. Hammoudeh,

A.,

$\mathrm{Abu}$

Hantash,H.,Tobbalat,R.,AlMousa,E., Madanat, E., AlMuhaisen, R., Fakhri,M., \& Alhaddad,I. (2020). The Covid-19 Pandemic and Triggered Acute Myocardial Infarction among NonInfected Individuals. International Journal of Clinical Cardiology,7(3).

2. العجرم، عبد السميع (2020). مدى مسؤولية الدولة عن تفثي فيروس كورونا وسبل مو اجهته و الحد منه: در اسة فقهية مقارنة: ليبيا نموذجاً. مجلة

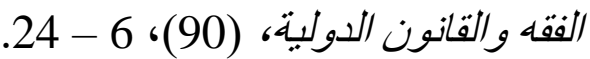

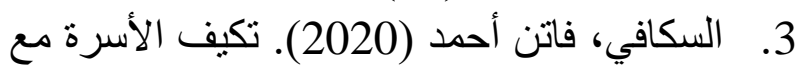
الحجر الصحي المنزلي في زمن كورونا. مجلة جيل العيل العلوم الإنسانية، (63)،

4. Cherry, K. (2020). How to cope with quarantine.

Retrieved

From

https://www.verywellmind.com/protect-yourmental-health-during-quarantine-4799766

5. Weir.K.(2020). Seven crucial research findings that can help people deal with COVID19.

Retrieved

From https://www.apa.org/news/apa/2020/03/covid19-research-findings
6. World
Health
Organization. (2020).Coronavirus disease
(COVID-19):

يتبين من الجدول (10) وجود فروق ذالئلة ذات دلالة

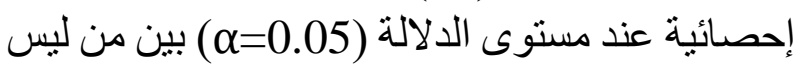

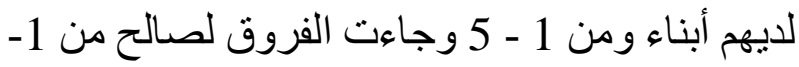

وقد تعزى هذه النتيجة إلى أن من لديهم أبناء من 1-5

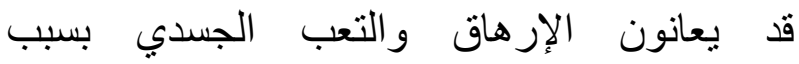
المسؤوليات التي يتحملونها مقارنة بمن ليس لديه أليناء

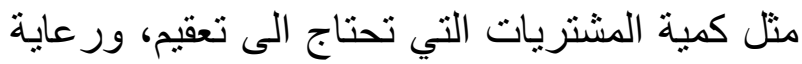
افر اد الاسرة، ومتابعة دروس الأبناء وتخفيف المئل

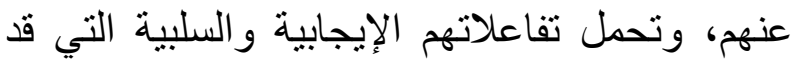
تؤدي الى بعض اضطر ابات النوم و الارهاق.وتتفق ولنق

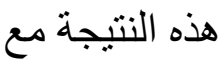
دراسة الفقي وأبو الفتوح [23] ودراسة [24] Mustafa Hammoudeh et al.

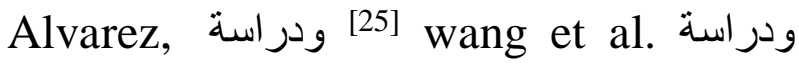
Rey, ودراسة 26] ودراسة Hernansaiz, and Collado من حيث وجود مستوى متوسط من الضغوط الناتجة عن انتشار

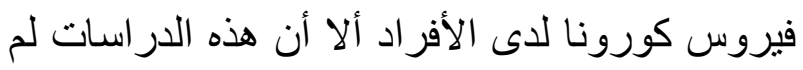
تبحث في الفروق التي تعزى لأثر عدد الأوناد لاد في الأن مستوى الضغوط النفسية.

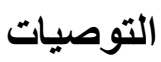

- تصميم برامج ارشادية لتخفيف الضغوط التوديات الموجودة لدى هذه الفئة. ـ ـفعيل الأسورة الإلكترونية بدلاً من الحجر الصحي

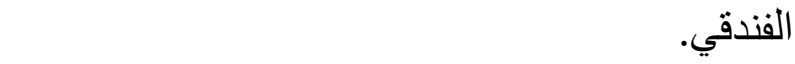
- منح الأفراد اجازات استثنائية بعد انتهاء جائحة كورونا والسماح لهم بالعودة للوطن ورؤية الأهل

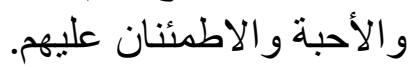


Disease. Retrieved From https://www.quebec.ca/en/health/health-issues/az/2019-coronavirus/stress-anxiety-and-depressionassociated-with-the-coronavirus-covid-19-disease/ 14. وزارة الداخلية السعودية (2020). الإجر اءات الاحتر ازية. استرجع من: https://twitter.com/MOISaudiArabia 15. Li, L. Cheng, S. Gu, J.(2003). SARS infection among health care workers in Beijing, China. JAMA. JAMA The Journal of the American Medical Association, 290 (20), 2662-2663.

16. الزيود، نادر فهي (2012). استراتيجيات التعامل مع الضغوط النفسية لدى طلبة جامعة قطر و علاقتها ببعض المتغيرات. مجلة رسالة الخلبج العربي، (1)، 32-99.

17. Lazarus.R.(1999).Hopei An emotion and avital coping resource against despair. Social Research,66(2), 202-216.

18. متولي، إبراهيم عباس (2000). الضغوط النفسية وعلاقتها بالجنس وبعض سمات الثخصية لاى معلمي المرحلة الابتدائية. المجلة المصرية

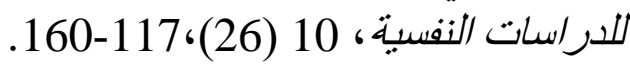

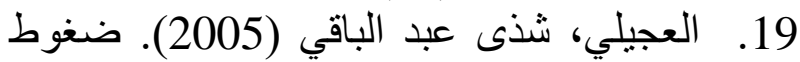

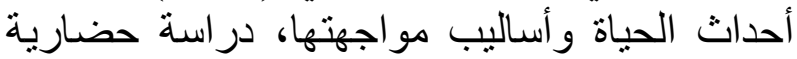

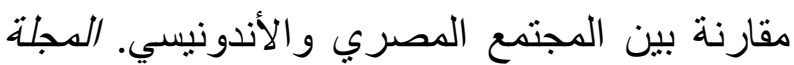

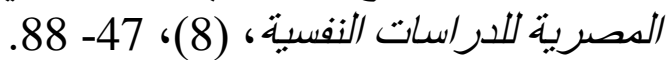

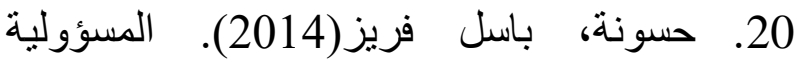
الاجتماعية والضغوط النفسية لدى القيادات الطلابية في جامعة القد المفتوحة. رسالة ماجستير غير منشورة، كلية التربية الجامعة الإسلامية. غزة الهة فلسطين.

21. علي، طلعت أحمد (2008). فعالية برنامج

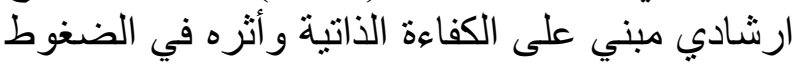
النفسية والدافعية للإنجاز لدى المعلمين في ضوه
What parents should know. Retrieved From https://www.unicef.org/stories/novelcoronavirus-outbreak-what-parents-shouldknow

$$
\begin{aligned}
& \text { 7. محمد، السيد نبيه (2020). فيروس كورونا بين } \\
& \text { ضرورتي اتخاذ تدابير الاحتو اء والالتز ام بالمعايير } \\
& \text { الدولية: أي بعد معياري لتدابير و إجر اءات التصدي التئي } \\
& \text { لفيروس .COVID-19 مجلة الباحث للدر اسات }
\end{aligned}
$$

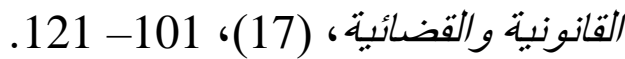

$$
\begin{aligned}
& \text { 8. زكريا، ميرفت (2020). أزمات متفاقمة :كورونا }
\end{aligned}
$$

9. Wilder, S., \& Freedman, M. (2020). Isolation, quarantine, social distancing and community containment: pivotal role for oldstyle public health measures in the novel coronavirus (2019-nCoV) outbreak. Journal of Travel Medicine, 27(2). Retrieved from https://academic.oup.com/jtm/article/27/2/taaa $\underline{020 / 5735321}$

10. النيسابوري، مسلم بن الحجاج (1991). صحبح مسلم. (تحقيق محمد فؤاد عبد الباقي) ط1، رقاج رقات 2218، ج 4 ص 1739. بيروت: دار احياء التراث العربي. 11. البيهقي، أحمد بن الحسين (2003). السنن الكبرى. (تحقيق محمد عبد القادر عطا) ط3، رقم 14244، ج 7 ص 356، بيروت: دار الكتب العلمية. 12.Bao, Y., Sun, Y., Meng, S., Shi, J., \& Lu, L.(2020). 2019-nCoV epidemic: address mental health care to empower society. Retrieved From https://www.sciencedirect.com/science/article/pii/S $\underline{0140673620303093}$

13.Québec (2020). Stress, Anxiety and Depression Associated With the Coronavirus COVID-19 
International Journal of Environmental Research and Public Health, 17(5), 1-25.

26. Alvarez,N., Lamas,R.,\&Olmos,C. (2020). Psychological effects and associated factors of COVID-19 in a Mexican sample. Disaster Medicine and Public Health Preparedness, 1-27. Retrieved From https://www.researchgate.net/publication/3424 23110 Psychological effects and associated factors of COVID-19 in a Mexican sample 27. Rey, R., Hernansaiz, H., \& Collado, S. (2020). Psychological Impact and Associated Factors During the Initial Stage of the Coronavirus (COVID-19) Pandemic Among the General Population in Spain. Frontiers in Psychology, 1511-1540. Retrieved From https://www.researchgate.net/publication/3420 55853_Psychological_Impact_and_Associated Factors During the Initial Stage of the Co ronavirus_COVID-

19_Pandemic_Among_the_General_Populatio n_in_Spain

\begin{abstract}
الكادر الخاص كما يدركه الطلاب. المجلة العلدية

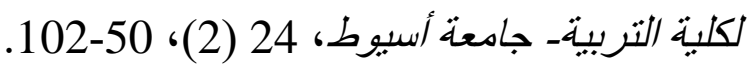

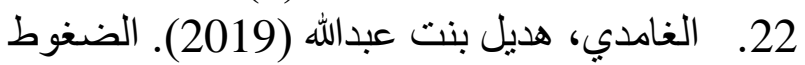

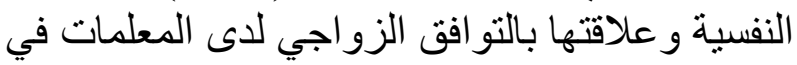
الباحة. مجلة كلية التربية- جامعة أسبيوط، 35 . 219 - 193 ، (6)

23. الفقي، آمال إبر اهيم؛ أبو الفتوح، محمد كمال

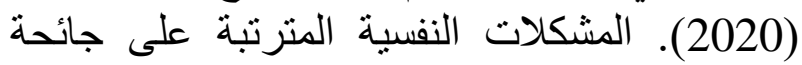

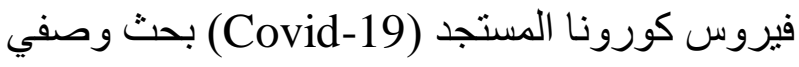

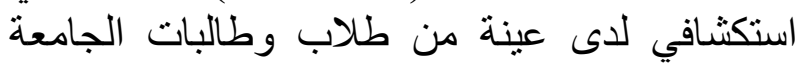

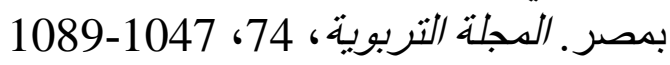

24. Mustafa ,N.(2020). Psychological Stress and Associated Factors during the Coronavirus Disease (COVID-19). International Journal of Science and Research (IJSR),10(4),12-18.

25. Wang, C., Pan, R., Wan, X., Tan, Y., $\mathrm{Xu}$, L., Ho, C., \& Ho, R. (2020). Immediate Psychological Responses and Associated Factors during the Initial Stage of the 2019 Coronavirus Disease (COVID-19) Epidemic among the General Population in China.
\end{abstract}

\title{
The level of psychological stress caused by spread of COVID-19 among a sample of Jordanians residing in Hail
}

\author{
Dr. Samar Seitan Al-Smadi \\ Assistant Professor, Department of Psychology, College of Education, \\ Hail University, Kingdom of Saudi Arabia. \\ Samarsmadi83@yahoo.com
}

\begin{abstract}
COVID-19. The study sample consisted of (161) person of Jordanians residing in Hail. To achieve the aim of the study, a descriptive approach was used, and the researcher built a scale and used it to measure the level of psychological stress. The study data were statistically analyzed using Pearson correlation, Cronbach-alpha, frequencies, means, standard deviations, T-test, One-way ANOVA, and Post Hoc comparisons (Scheffe test). The results showed a Moderate level of psychological stress, among a person on the scale as a whole and in all parts. There were also statistically significant differences attributable to the impact of gender, social status, number of children. and differences came in favor of females on the scale as a whole and in
\end{abstract}


all parts, and in favor of married status and persons who had 1-5 children on the scale as a whole and on the physical side. The study recommends: Designing counseling programs to relieve psychological stress on this group, and to conduct more research on the impact of the spread of the epidemic in societies on the psychological state and its impact on family life, professional performance, give persons' exceptional holidays after the end of the Corona pandemic and allowing them to return to the homeland and see their families.

Keywords: Home quarantine, precautionary measures, Social spacing, Curfew, psychological stress. 